\title{
Permian magmatism and metamorphism in the Dent Blanche nappe: constraints from field observations and geochronology
}

\author{
Paola Manzotti ${ }^{1}$ (1) Daniela Rubatto ${ }^{1,2,3} \cdot$ Michele Zucali $^{4} \cdot$ Afifé El Korh $^{2,5}$ • \\ Bénédicte Cenki-Tok $^{6} \cdot$ Michel Ballèvre $^{7} \cdot$ Martin Engi $^{2}$
}

Received: 25 January 2017/ Accepted: 3 September 2017

(C) Swiss Geological Society 2017

\begin{abstract}
In the Dent Blanche Tectonic System, the Mont Morion biotite-bearing granite is a $\mathrm{km}$-scale intrusion preserved in a low-strain volume. Zircon saturation thermometry suggests that it crystallised from a melt that reached about $800{ }^{\circ} \mathrm{C}$. U-Pb zircon and allanite geochronology indicates crystallization of the magma in the Permian ( $290 \pm 3 \mathrm{Ma} ; 280 \pm 8 \mathrm{Ma}$, respectively). Migmatitic biotite-gneiss and amphibolite are found as xenoliths within the Mont Morion granite and constitute its country-rocks. In two samples of migmatitic biotite-gneiss
\end{abstract}

Editorial handling: E. Gnos.

Electronic supplementary material The online version of this article (doi:10.1007/s00015-017-0284-1) contains supplementary material, which is available to authorized users.

Paola Manzotti

paola.manzotti@gmail.com

1 Institute of Earth Sciences, University of Lausanne, Géopolis, Quartier Mouline, 1015 Lausanne, Switzerland

2 Institute of Geological Sciences, University of Bern, Baltzerstrasse 1+3, 3012 Bern, Switzerland

3 Research School of Earth Sciences, Australian National University, Canberra, ACT 2601, Australia

4 Dipartimento di Scienze della Terra "Ardito Desio", Università degli Studi di Milano, Via Mangiagalli, 34-20133 Milano, Italy

5 Unit of Earth Sciences, Department of Geosciences, University of Fribourg, Chemin du Musée 6, 1700 Fribourg, Switzerland

6 Géosciences Montpellier UMR 5243-CC. 60, Université Montpellier 2, Place E. Bataillon, 34095 Montpellier Cedex 5, France

7 Géosciences Rennes, UMR 6118-CNRS, Université Rennes1, Campus de Beaulieu, 35042 Rennes, France zircon has metamorphic overgrowths that yield $\mathrm{U}-\mathrm{Pb}$ ages of $285 \pm 3 \mathrm{Ma}$ and $281 \pm 4 \mathrm{Ma}$, and are thus contemporaneous with the intrusion of the granite. The Mont Morion granite with its country-rocks of migmatitic biotite-bearing gneiss and amphibolite was thus emplaced at middle crustal levels while amphibolite facies metamorphism affected its country rocks. The magmatic and metamorphic record in the Mont Morion area reflects the high-temperature regime and lithospheric thinning of the Adriatic continental margin during Permian.

Keyword Permian magmatism - Regional HT metamorphism · Allanite $\cdot$ Zircon $\cdot$ Sesia-Dent Blanche nappes · Alps

\section{Introduction}

The high thermal regime that characterised the European Alpine region during the Permian was responsible for diffuse magmatism with gabbroic and granitic intrusives at all crustal levels (e.g., Paquette et al. 1989; Bussy et al. 1998; Monjoie et al. 2007; Cenki-Tok et al. 2011; Miller et al. 2011) and explosive, acid volcanism at the surface (e.g., Quick et al. 2009). This igneous activity was associated with high temperature medium/low pressure metamorphism in the lower and middle continental crust (e.g., Rivalenti et al. 1984; Sinigoi et al. 1994; Peressini et al. 2007; Manzotti et al. 2012; Zanetti et al. 2013; Klötzli et al. 2014). Both magmatic and metamorphic signals have been interpreted as the result of a hot astenospheric mantle upwelling under the continental plate and of continental rifting (e.g., Dal Piaz and Martin 1988; Dal Piaz et al. 1993; Diella et al. 1992; Marotta and Spalla 2007; Müntener et al. 2001; Schuster and Stüwe 2008). 
In the Dent Blanche Tectonic System (DBTS) (Fig. 1), the Arolla Series is classically considered as a slice $(\sim 50 \times 5 \mathrm{~km})$ of Permian upper continental crust (e.g., Argand 1911; Diehl et al. 1952; Dal Piaz et al. 1972, 2015; Manzotti et al. 2014a). It mostly comprises intrusive bodies (granitoids, diorite and gabbro) (Dal Piaz et al. 2015 and references therein) that were metamorphosed and deformed at low-temperature high-pressure conditions, during the Alpine orogeny (Roda and Zucali 2008; Angiboust el al. 2014). The Permian age of the Arolla Series is well established for the mafic to ultramafic igneous rocks (Dal Piaz et al. 1977; Bussy et al. 1998; Monjoie et al. 2005, 2007). By contrast, the age of the granitoids is generally assumed to be Permian, but this has been assessed in a single study (ID-TIMS), for an orthogneiss sampled south of the Matterhorn (Bussy et al. 1998). The Mont Morion granite $(\sim 7 \times 1.5 \mathrm{~km})$ is the largest undeformed granitoid body in the Arolla Series (e.g., Diehl et al. 1952; Roda and Zucali 2008), and it preserves igneous texture and mineralogy. Moreover, metre-scale enclaves of migmatitic biotite-gneiss and amphibolite recording high temperature metamorphism are found as xenoliths within this pluton (e.g., Diehl et al. 1952; Pennacchioni and Guermani 1993; Roda and Zucali 2008). These lithologies also form a kilometre-scale body interpreted as countryrocks (Burri et al. 1999). The age of the high temperature metamorphism in these bodies has not been established so far and their time relationship to the emplacement of the pluton remains unclear. The Mont Morion granite is thus an excellent setting to study the age of the magmatism in the DBTS and to discuss its temporal relationship to Permian high temperature metamorphism that is widely recorded in the Adriatic crust. This study presents field and geochronological (U-Pb ages of allanite and zircon) data for the Mont Morion granite. In addition, thermometry on metamorphic biotite, $\mathrm{U}-\mathrm{Pb}$ ages and geochemistry of zircon are reported for two samples of migmatitic biotitegneiss. These data allow discussing the age and characteristics of the high temperature metamorphism for the migmatitic biotite-gneiss.
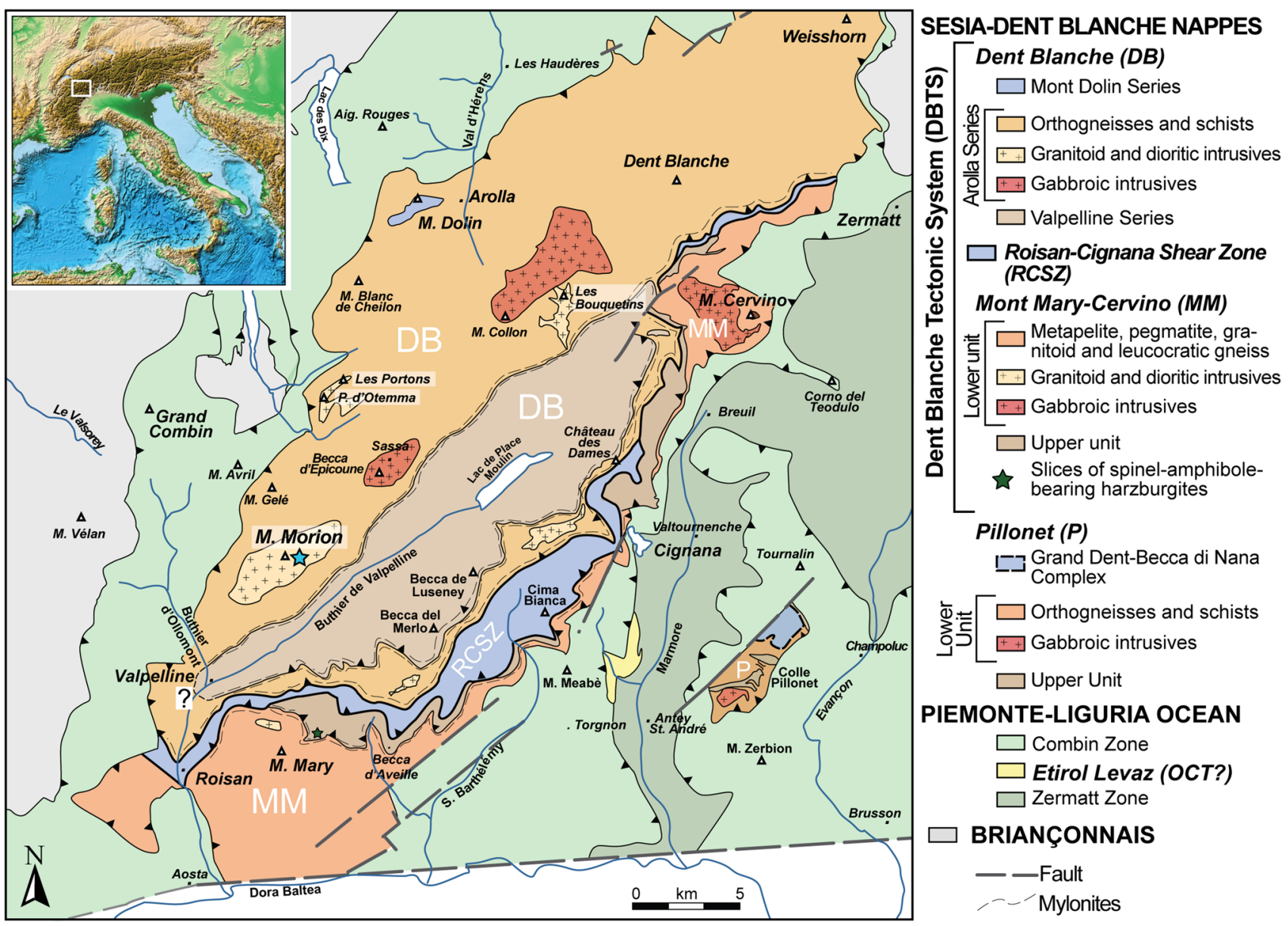

Fig. 1 Geological map of the Dent Blanche Tectonic System (DBTS), showing the main undeformed gabbroic and granitic intrusives (modified after Manzotti et al. 2014b). The blue star indicates the location of Fig. 2 


\section{Geological setting}

The internal Western Alps consist predominantly of continental and oceanic derived units, which were assembled during the oblique Alpine convergence of S-Europe and the thinned Adriatic margin (Schmid et al. 2004; Handy et al. 2010). The Sesia-Dent Blanche nappes derive from the Adriatic palaeomargin and mainly consist of polycyclic basement slices, bounded by Alpine shear zones and now forming independent tectonic units. These units preserve evidence of the pre-Alpine (Permian) magmatism and metamorphism (e.g. Carraro et al. 1970; Compagnoni 1977; Lardeaux and Spalla 1991; Manzotti et al. 2014a, b).

The DBTS is a large continental klippe, resting on top of the Piemonte-Liguria ocean and surfacing to the north of the Aosta valley (Fig. 1). The DBTS is made of the Dent Blanche (DB) and the Mont Mary-Cervino (MM) nappes (Fig. 1) that are separated by the Roisan-Cignana Shear Zone (RCSZ), an Alpine km-scale high strain zone (Manzotti 2011; Manzotti et al. 2014b). The Dent Blanche nappe comprises the Valpelline Series and the Arolla Series (Diehl et al. 1952), as well as remnants of a Mesozoic metasedimentary cover (i.e., the Mt. Dolin Series, Ayrton et al. 1982).

The Valpelline Series consists of meta-pelite, mafic and carbonate rocks with a dominant metamorphic imprint under amphibolite to granulite facies conditions (Nicot 1977; Gardien et al. 1994; Manzotti and Zucali 2013) of Permian age (Zucali et al. 2011; Kunz et al. 2017). Anatectic veins and dykes of garnet-bearing pegmatite are common (Diehl et al. 1952; Nicot 1977). The Alpine imprint is weakly developed and mainly at greenschist facies, but a few occurrences of kyanite-chloritoid assemblages in the Valpelline Series have been interpreted as evidence of relatively high pressure conditions (e.g. $7-8$ kbar) during the Alpine orogeny (Kiénast and Nicot 1971).

The Arolla Series is dominantly made of several intrusive bodies of granitoids, some of them preserving undeformed portions (e.g., Mont Morion, Les Bouquetins, Les Portons, P. d'Otemma) and their orthoderivates (Diehl et al. 1952; Burri et al. 1999; Roda and Zucali 2008; Dal Piaz et al. 2015). Migmatitic biotite-bearing gneiss and amphibolite occur sparsely within the intrusives and constitute a kilometre-scale body (Diehl et al. 1952; Burri et al. 1999; Roda and Zucali 2008; Dal Piaz et al. 2015; Manzotti et al. 2017). Several gabbro bodies of various sizes have been described in the Dent Blanche s.s. (Mont Collon-Dent de Bertol, Ruinette, Sassa, and Berrio) and Mont-MaryCervino nappe (Becca d'Aveille, Matterhorn-Cervino) (Dal Piaz et al. 1977, 1997, 2010, 2015; Dal Piaz and Martin 1988; Burri et al. 1999; Monjoie et al. 2007; Baletti et al.
2012; Manzotti et al. 2017). Both granitoids and gabbros largely preserve their pre-Alpine igneous texture and mineralogy. Permian ages have been determined for the Mont Collon and Cervino gabbros $(284 \pm 1 \mathrm{Ma}, \mathrm{U} / \mathrm{Pb}$ on zircon; Monjoie et al. 2005; $250 \pm 5 \mathrm{Ma}, \mathrm{K} / \mathrm{Ar}$ and $\mathrm{Rb} / \mathrm{Sr}$ methods, Dal Piaz et al. 1977), as well as for a greenish orthogneiss sampled south of the Matterhorn (289 $\pm 2 \mathrm{Ma}$, $\mathrm{U} / \mathrm{Pb}$ on zircon, Bussy et al. 1998). In the Arolla Series, the Alpine evolution is characterised by blueschist (rare relics only) and then greenschist facies conditions (Diehl et al. 1952; Roda and Zucali 2008; Angiboust et al. 2014), frequently associated with ductile Alpine deformation.

\section{Field relationships of the magmatic bodies in the studied area}

Recent field study has led to the identification of three main subunits forming the Arolla Series, namely the Mont Morion, Mont Gelé and Regondi Units (for details, see Manzotti et al. 2017). In the Mont Morion Unit, a low strain domain has been reported by previous authors (Diehl et al. 1952; Burri et al. 1999; Roda and Zucali 2008, 2011; Dal Piaz et al. 2015; Manzotti et al. 2017). The different lithologies constituting this domain crop out in two small tributaries on the right side of the Valpelline valley, namely the Comba di Crête Sèche and the Comba Faudery (Figs. 2 and 3), which are more easily accessible and less prone to rock falls than the Mont Morion ridge itself (Fig. 3). The following description is based on previous work (Diehl et al. 1952; Burri et al. 1999; Roda and Zucali 2008, 2011; Dal Piaz et al. 2015) and our own field data, summarized in a new map (Fig. 2a) and a cross-section (Fig. 2b).

\subsection{Main lithologies}

From north to south, three main lithologies are exposed. (1) An amphibole-bearing granite (Fig. 4a) that displays a porphyritic structure with phenocrysts of K-feldspar (1-5 cm in size) within a matrix that contains biotite, hornblende, plagioclase (now commonly saussurritic) and quartz (up to $1 \mathrm{~cm}$ in size). This granite shows a magmatic foliation marked by the shape preferred orientation of K-feldspar, plagioclase, and amphibole (Fig. 4a). Mafic microgranular enclaves (Fig. 4a) are decimetre to metre in size, of lenticular shape and elongated parallel to the magmatic foliation. They consist of hornblende, saussuritic plagioclase and rare biotite. These enclaves may derive from more ancestral magmas or from dikes intruding the granitic melt and dismembered by the movement of the granitic magma (e.g. Didier and Barbarin 1991). A pervasive foliation (Fig. 4b) defined by millimetre- to centimetre-scale flattened feldspar pseudomorphs and quartz 


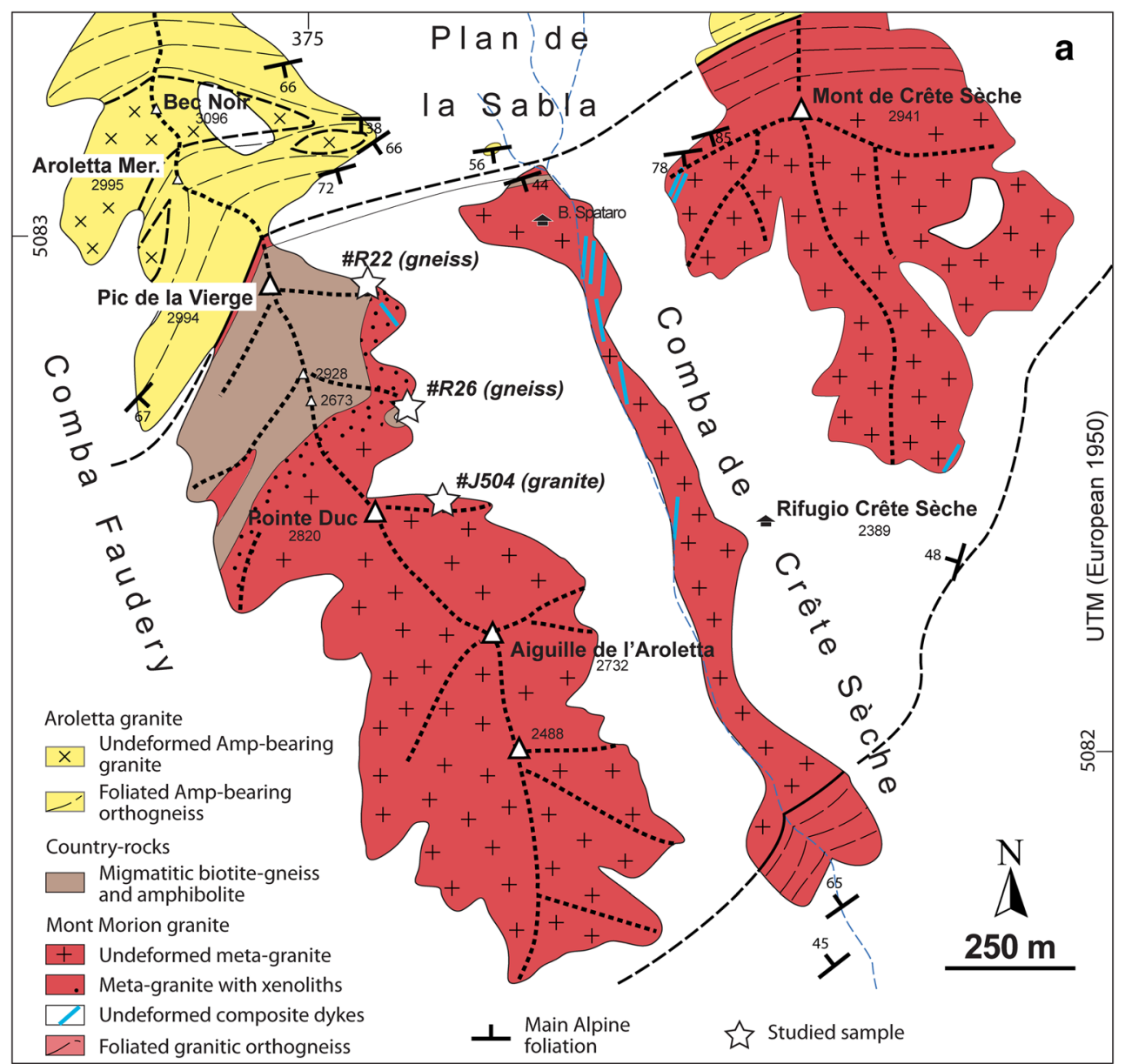

SSE

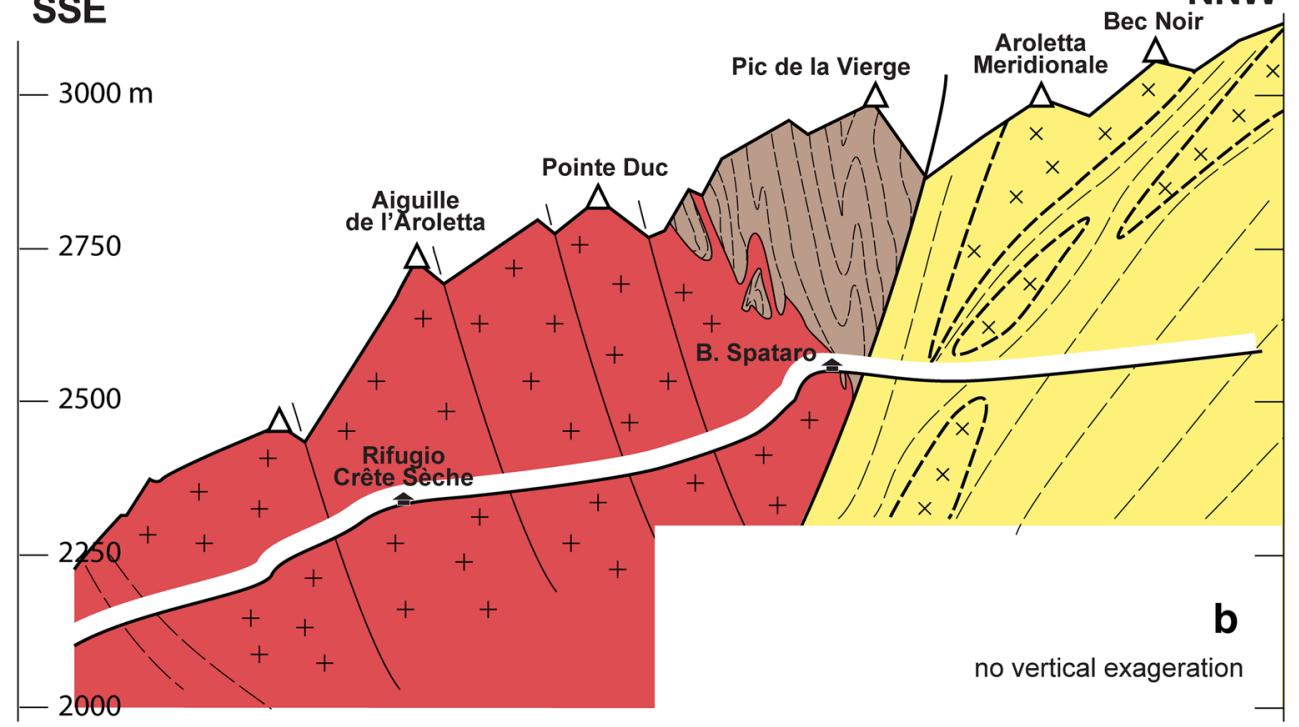

Fig. 2 a Geological map of the Mont Morion Unit in the area of the Comba de Crête Sèche. Stars indicate the location of the studied samples. The original geological mapping was undertaken at 1:10,000 scale, using as topographic base the "Carta Tecnica Regionale", Regione Valle d'Aosta, UTM ED 1950 coordinate system. The map has been redrawn on the georeferenced topographic map n1366
"Mont Vélan" edited by the Swiss Federal Office of Topography, "Swisstopo". b Schematic cross-section of the Comba de Crête Sèche. Note the largely undeformed body of the Mont Morion granite, intruding partially melted gneiss and amphibolite, both being separated from the heterogeneously deformed Aroletta granite by a ductile shear zon 

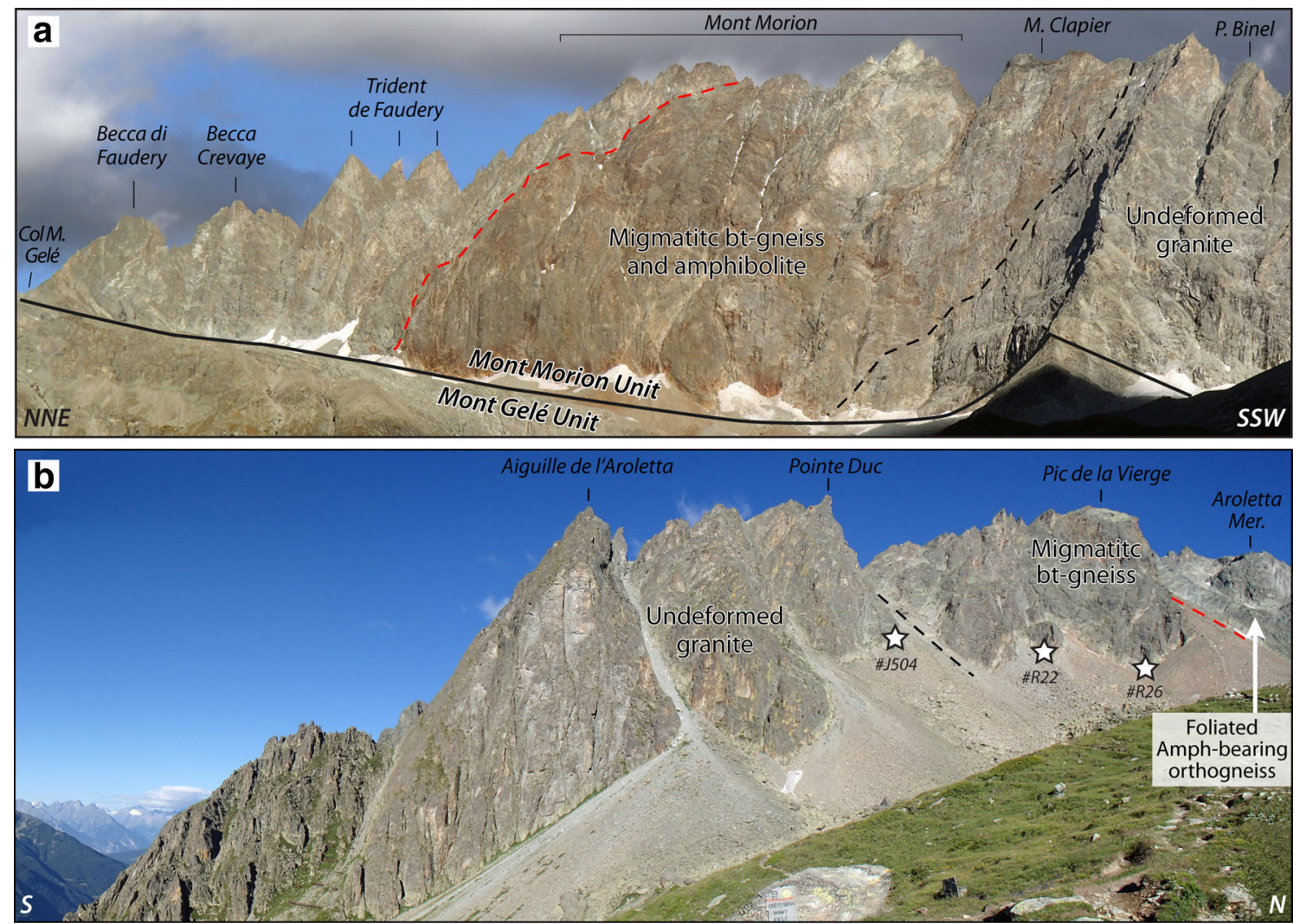

Fig. 3 Panoramic views of the studied area. UTM coordinates for each photograph are given. a Western flank of the Mont Morion chain (373168/5082658). The $\sim 500 \mathrm{~m}$ thick country-rocks consisting of migmatitic biotite-gneiss and amphibolite show the typical redweathering colour. The intrusive contact between the Mont Morion granite and the country-rocks (dashed black line) is cut by the

aggregates developed during the Alpine evolution and bounds metre- to decametre-scale lower strain domains. Coronas of pale green amphibole grew around the magmatic hornblende.

(2) A kilometre-scale body ( $\sim 2 \mathrm{~km}$ long and $500 \mathrm{~m}$ thick) of migmatitic biotite-gneiss and interlayered amphibolite is cropping out from the base of the Mont Morion cliff to the west to the Pic de la Vierge to the east (Fig. 2). The migmatitic biotite-gneiss comprises biotite, quartz, and feldspar whereas amphibolite consists of green hornblende and plagioclase \pm minor biotite. Evidence for partial melting (Fig. 4c) in the paragneiss is provided by coarse-grained leucocratic layers made of quartz and feldspars (i.e., leucosomes), bordered by narrow biotiterich selvedges (i.e., melanosomes). The proportion of leucosome may reach up to c. $30 \%$ in volume. Pegmatitic layers (Fig. 4d), up to one metre thick, are parallel to the migmatitic layering, and display garnet (up to $1 \mathrm{~cm}$ in size) sometimes associated with muscovite. In the amphibolite, coarse-grained leucosomes consisting of mylonitic contact at the base of the Mont Morion Unit (continuous black line). b Eastern flank of the Aroletta ridge (375216/5082547). The dashed black line marks the intrusive contact between the Mont Morion biotite-bearing granite and the migmatitic biotite-gneiss, whereas the dashed red line marks the tectonic contact between the migmatitic biotite-gneiss and the Aroletta amphibole-bearing granite

clinopyroxene (frequently rimmed by amphibole), plagioclase, and quartz form irregular $\mathrm{cm}$ - to $\mathrm{dm}$-scale patches or veins (Fig. 4e). The amount of leucosome in the amphibolite is much smaller ( $5-10 \%$ at most in volume) than in the paragneiss.

(3) In the southern part, a medium- to coarse-grained biotite-bearing granite locally displaying a weak to moderate magmatic foliation constitutes the larger part of the outcrop. Accessory minerals are zircon, titanite, apatite and allanite. Numerous composite dykes are seen along the Comba de Crête Sèche, especially along the footpath from the Rifugio Crête Sèche to the Bivacco Spataro (Fig. 2), and at the base of the cliff of the Mont Crête Sèche. In the dykes, felsic magma forms an anastomosing net of cmscale veins which enclose decametric lenses of finergrained mafic material, sometimes showing $\mathrm{cm}$-sized amphibole needles aligned parallel to the mafic bodies and to the main trend of the felsic veins (Figs. 4f, 5a). Detailed examination in the field of the composite bodies reveal that they have a tabular shape, 1-3 metres in thickness, and 

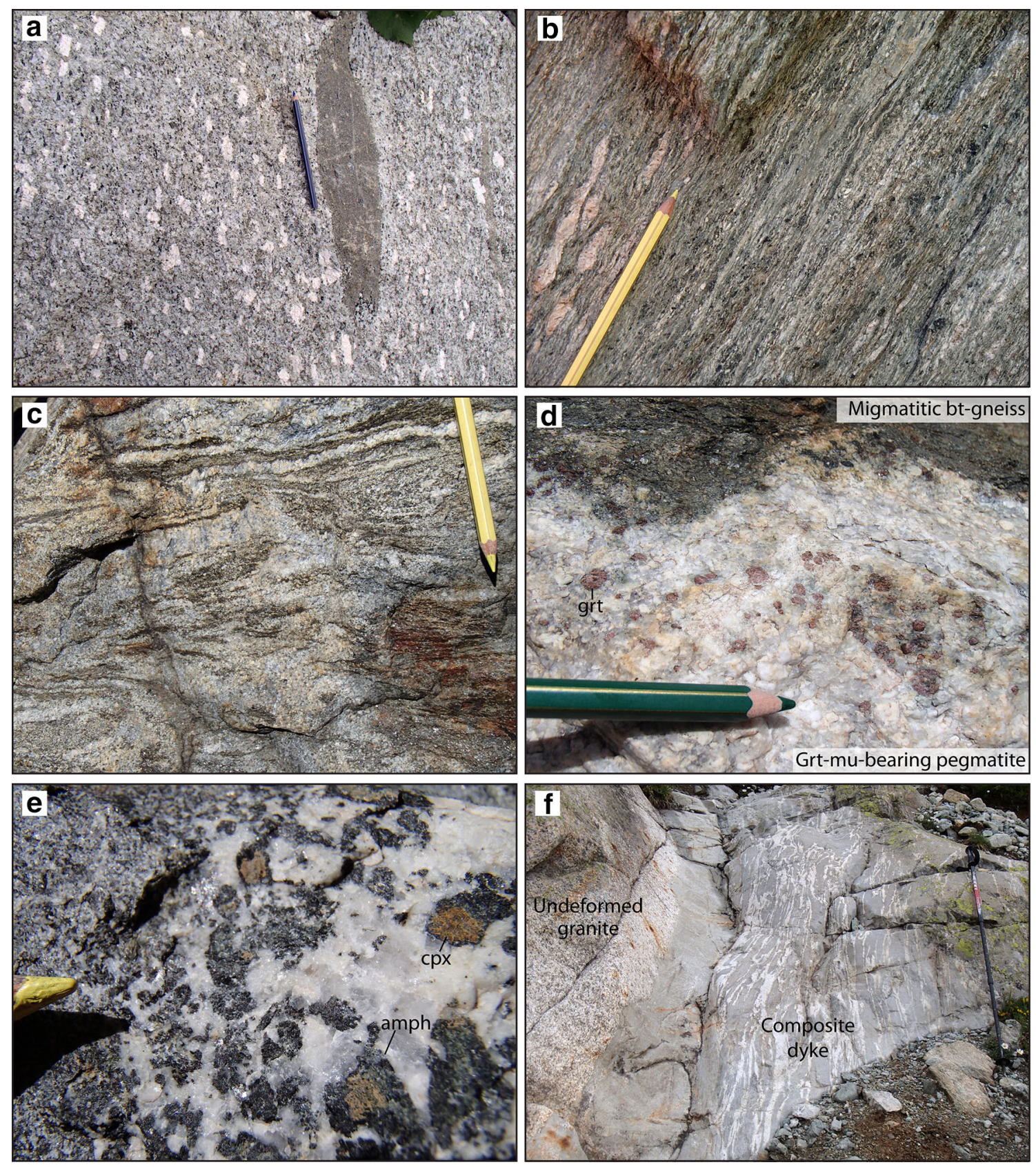

Fig. 4 Petrographic characterisation of the main lithologies in the studied area. UTM coordinates for each photograph are given. a Typical field aspect of the Aroletta amphibole-bearing granite (374861/5083365). A magmatic foliation is defined by the shape preferred orientation of K-feldspar and amphibole. A mafic microgranular enclaves is elongated parallel to the magmatic fabric. b Foliated Aroletta amphibole-bearing granite, characterised by centimetre-scale recrystallized K-feldspar (347996/5083519). c Migmatitic biotite-gneiss (375160/5082825) showing coarse-grained

rather sharply cutting the biotite-bearing granite (Figs. 4f, 5a). The fabric inside the composite bodies is parallel to their margins, but at high angle with respect to the magmatic foliation in the enclosing granite.

leucocratic layers made of quartz and feldspar (leucosomes), bordered by narrow biotite-rich selvedges (melanosomes). d Garnet-muscovite bearing pegmatite, parallel to the migmatitic layering and displaying cm-size garnet crystals (375416/5082788). e Coarse-grained leucosome consisting of clinopyroxene crystals rimmed by amphibole, plagioclase and quartz in a partially melted amphibolite (374739/ 5082534). f Mont Morion biotite-bearing granite cut by a composite dyke (375523/5082870). The dyke displays an anastomosing net of felsic veins, which enclose lenses of finer-grained mafic material

\subsection{Structural relationships}

A primary task of the field work was to determine whether the contacts between the three lithologies distinguished above are either preserved intrusive contacts, or tectonic 

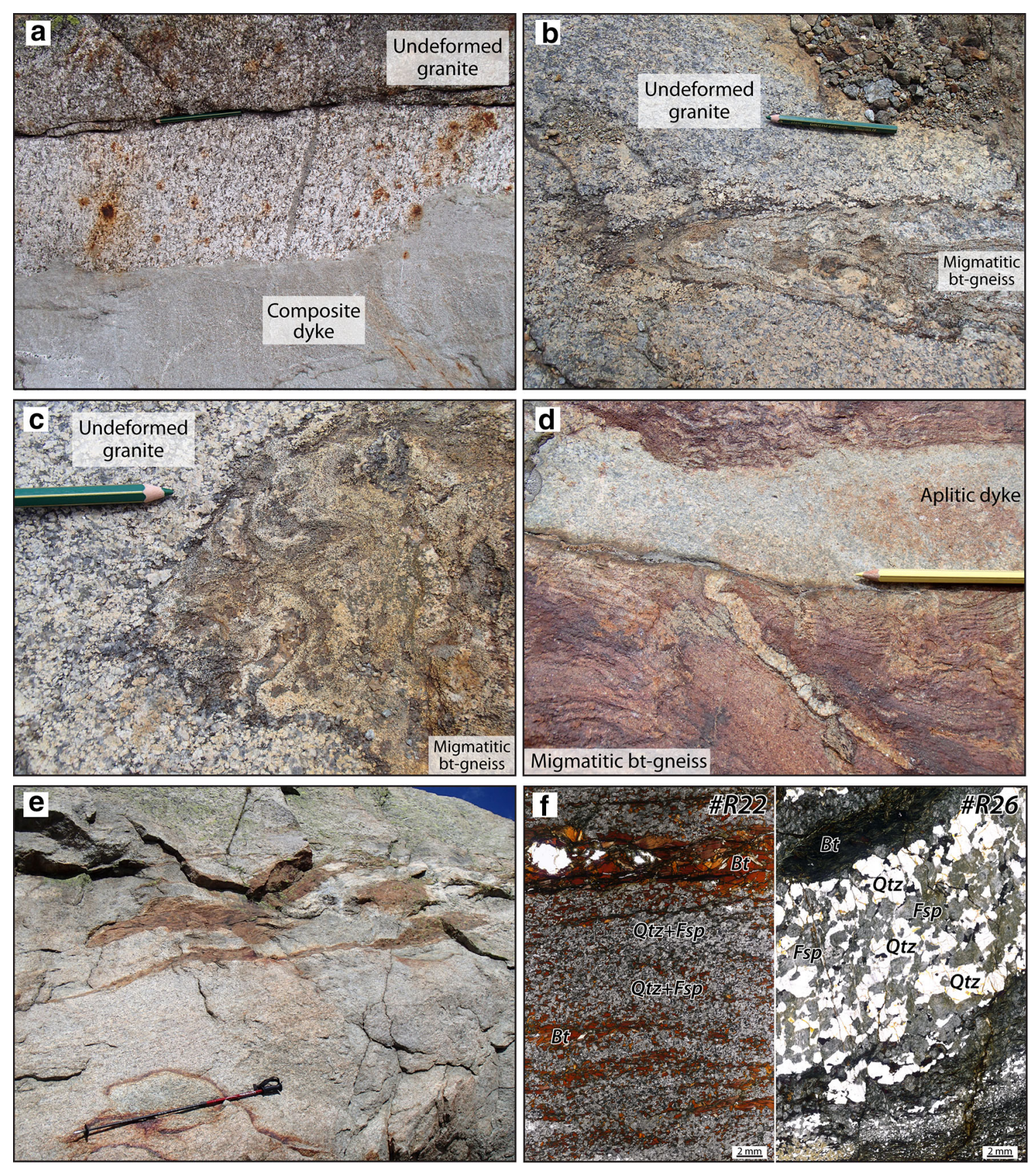

Fig. 5 Structural relationships of the main lithologies in the studied area. UTM coordinates for each photograph are given. a Note that the enclave in the Mont Morion biotite-bearing granite is elongated parallel to the magmatic fabric, but perpendicular to the composite dyke (375523/5082870). The dyke shows a tabular shape and an internal fabric parallel to its margin. $\mathbf{b}, \mathbf{c}$ Detail of the contact between the migmatitic biotite- gneiss and the Mont Morion biotite-bearing granite: a centimetre-thick selvedge of biotite develops at the interface between the granite and the gneiss (375408/5082762). The contact is gently folded. $\mathbf{d}$ An aplitic dyke cuts the migmatitic biotite-

boundaries (pre-Alpine or Alpine in age). Prior authors have suggested that the biotite-gneiss and amphibolite represent either the country-rocks of the intrusive granites (Burri et al. 1999) or roof-pendants and/or xenoliths (Diehl

gneiss (375490/5082651). e Metre-scale xenoliths of migmatitic biotite-gneiss in the Mont Morion biotite-bearing granite in the proximity of the contact between the Mont Morion biotite-bearing granite itself and the main gneissic body at the foot of the Pic de la Vierge (375196/5082809). Note the elongation of the xenoliths parallel to the magmatic foliation in the Mont Morion granite. f Photomicrographs of migmatitic biotite-gneiss. Biotite films (melanosomes) and quartz-feldspar layers (leucosomes) define the migmatitic layering (plane-polarized light)

et al. 1952; Pennachioni and Guermani 1993; Roda and Zucali 2008, 2011).

Field observations show a sharp contact between the amphibole-bearing granite and the migmatitic biotite- 
gneiss, from slightly north of the Pic de la Vierge to slightly south of the Mont de Crête Sèche (Fig. 2). In this area, no evidence for xenoliths of migmatitic biotitegneisses into the amphibole-bearing granite has been found. In addition, no evidence for dykes of this granite into the migmatitic biotite-gneiss has been observed. A pervasively foliated domain, 10-100 metres thick, bounds the southern margin of the amphibole-bearing granite. We conclude that the contact is most probably tectonic, either pre-Alpine (e.g., a Permian shear zone, a normal fault of Jurassic age) or Alpine (an internal thrust in the Mont Morion Unit).

By contrast, the intrusive contact of the biotite-bearing granite into the migmatitic biotite-gneiss is undisputable. This relies on several lines of evidence, mostly observed along the southern margin of the migmatitic body, either along the base of the cliff, or, in huge blocks in the scree along the flanks of both Comba Faudery and Comba de Crete Sèche. Firstly, the contact between the granite and the migmatitic biotite-gneiss is in most cases lobate and/or cuspate, displaying open to narrow folds of decimetre- to metre-scale (Fig. 5b, c). Towards such folded contacts, no variation of grain size is observed in the granite. A centimetre-thick selvedge of biotite develops at the interface between the granite and the gneiss (Fig. 5b, c). In addition, leucosome layers inside the migmatitic biotite-gneiss are parallel to or sometimes cut by the contact, and later folded with the same axial plane than the granite-gneiss contact. Secondly, aplitic dykes are commonly cutting the migmatitic biotite-gneisses (Fig. 5d) as well as the folded contact between the gneisses and the biotite granite. Another evidence for intrusive contact is the presence of numerous metre- to decametre-sized xenoliths of migmatitic biotitegneiss into the biotite-bearing granite (Fig. 5e), at a distance not exceeding about $50 \mathrm{~m}$ from the main gneissic body.

Last but not least, composite dykes have been found over large areas in the biotite-bearing granite, including cutting across the contact between the latter and the gneiss (e.g., at the departure of the climbing route to the Pic de la Vierge called Oriana). By contrast, such composite dykes have never been observed in the amphibole-bearing granite.

\subsection{Relative timing deduced from field relationships}

For clarity, hereafter the amphibole-bearing granite is called the Aroletta Granite and the biotite-bearing granite the Mont Morion Granite. The two granitic bodies are separated by a shear zone and no age relationships between the two can be deduced from the field data.

By contrast, field data allow the recognition of different stages in evolution of the Mont Morion granite and country rocks:
- sedimentation of the protoliths of the gneiss and mafic magma emplacement (now amphibolite layers within the gneiss);

- high-grade metamorphism (i.e., partial melting) of both the sediments and the mafic magmas;

- intrusion of the biotite-bearing granite at a time when the migmatitic gneiss and amphibolite were still not cooled, allowing folding of the granite-gneiss contact with small temperature difference between the two, hence no recognizable thermal overprint in the gneiss due to the granite intrusion;

- cooling of this piece of crust as evidenced by intrusion of composite dykes;

- further cooling of the magmatic body and its gneissic country-rocks, allowing aplitic dykes to cut across the contact.

The main focus of our geochronological study is to date the oldest metamorphic and magmatic stages in this sequence, namely the partial melting in the biotite-gneiss, and the intrusion of the Mont Morion granite.

\section{Analytical methods}

\subsection{Imaging and electron probe microprobe analysis (EMPA)}

Allanite electron-microprobe analyses on major and accessory minerals were performed on polished thin sections with a JEOL JXA8200 electron microprobe (EMPA) at the University of Bern, using the analytical scheme described by Scherrer (2000) and refined by Janots et al. (2008). Operating conditions were set to $15 \mathrm{kV}$ and $20 \mathrm{nA}$ (spot size $=1 \mu \mathrm{m})$ for major minerals and $25 \mathrm{kV}$ and $50 \mathrm{nA}$ ( for all the REE-minerals analyses. $\varphi(p Z)$ matrix correction was applied based on Armstrong (1988, 1991). Natural silicates and oxides were used as standards and as monitors to check the accuracy of measurements. Back scattered electron images were obtained with a ZEISS EVO50 scanning electron microscope (University of Bern) using a voltage of $20 \mathrm{kV}$, current of $\sim 1 \mathrm{nA}$ and a working distance of $10 \mathrm{~mm}$, and with a Cambridge S360 scanning electron microscope (Centre for Advanced Microscopy, Australian National University), using a voltage of $20 \mathrm{kV}$, beam current of $\sim 2 \mathrm{nA}$ and a working distance of $17 \mathrm{~mm}$. Cathodoluminescence (CL) investigation was carried out on a HITACHI S2250 N scanning electron microscope supplied with an ellipsoidal mirror for CL at the ANU Centre for Advanced Microscopy. Operating conditions for the SEM were $15 \mathrm{kV} / 60 \mu \mathrm{A}$ and $20 \mathrm{~mm}$ working distance.

Chlorite, feldspar and biotite, mineral analyses were performed with a Cameca SX100 electron microprobe 
(Microsonde Ouest, Brest, France) operating in the wavelength dispersive mode. Operating conditions for spot analyses were set to $15 \mathrm{keV}, 20 \mathrm{nA}$ and $10 \mathrm{~s}$ counting time on the peak (spot size $=1 \mu \mathrm{m}) . \varphi(p Z)$ matrix correction was applied based on Pouchou and Pichoir (1985). Standards were natural albite $(\mathrm{Na}, \mathrm{Si})$, orthoclase $(\mathrm{K})$, corun$\operatorname{dum}(\mathrm{Al})$, wollastonite $(\mathrm{Ca})$, forsterite $(\mathrm{Mg}), \mathrm{MnTiO}_{3}(\mathrm{Mn}$, $\mathrm{Ti}$ ), andradite $(\mathrm{Fe})$. Representative analyses of biotite, chlorite and feldspar are given in Tables S3, S4 and S5.

\subsection{Allanite and zircon ion microprobe dating}

Samples were disintegrated using a SELFRAG apparatus to a grain size of $\sim 250$ microns at the University of Bern. Zircons and allanite grains were separated using conventional heavy liquid and magnetic properties. Grains for SHRIMP analysis were mounted in epoxy resin and polished down to expose the grains near their centres.

$\mathrm{U}-\mathrm{Pb}$ analyses of allanite and zircon (\#J504) were obtained with a SHRIMP II ion microprobe at the ANU in Canberra. Instrumental conditions and data acquisition were generally as described by Williams (1998). The data were collected in sets of six scans throughout the masses, and a reference zircon was analysed each fourth analysis. The measured ${ }^{206} \mathrm{~Pb} /{ }^{238} \mathrm{U}$ ratio was corrected using reference zircon from the Temora granodiorite (TEM, Black et al. 2003). The calibration error for the session was $1.8 \%$ (two sigma) and it was propagated to the individual analysis. The fraction of non-radiogenic ${ }^{206} \mathrm{~Pb}\left(\mathrm{f}_{206}\right)$ was calculated from the measured ${ }^{207} \mathrm{~Pb} /{ }^{206} \mathrm{~Pb}\left({ }^{7 / 6} \mathrm{R}_{\mathrm{m}}\right)$ and the nonradiogenic ${ }^{207} \mathrm{~Pb} /{ }^{206} \mathrm{~Pb}\left({ }^{7} \mathrm{R}_{\mathrm{c}}\right)$ according to Williams (1998), i.e., $\mathrm{f}_{206}=\left({ }^{7 / 6} \mathrm{R}_{\mathrm{m}}{ }^{-7 / 6} \mathrm{R}^{*}\right) /\left({ }^{7 / 6} \mathrm{R}_{\mathrm{c}}{ }^{-{ }^{7 / 6}} \mathrm{R}^{*}\right)$, where ${ }^{7 / 6} \mathrm{R}^{*}$ is the expected radiogenic ${ }^{207} \mathrm{~Pb} /{ }^{206} \mathrm{~Pb}$ assuming concordance at the approximate age of the sample. The ${ }^{7} R_{c}$ composition was assumed to be as predicted by the Stacey and Kramers (1975) model. Uncertainties on average ages were forced to be at least $1 \%$ to account for external errors and long term reproducibility.

For allanite, instrumental conditions and data acquisition were as described by Gregory et al. (2007), with isotope data collected from sets of six scans through the masses. U-Th- $\mathrm{Pb}$ allanite data were collected over a single analytical sessions with a calibration error of $1.5 \%$ (two sigma), which was propagated to single analyses. The measured ${ }^{208} \mathrm{~Pb} /{ }^{232} \mathrm{Th}$ ratio was corrected using the allanite standard TARA. A secondary standard (Bona ${ }^{208} \mathrm{~Pb} /{ }^{232} \mathrm{Th}$ age of $30.1 \mathrm{Ma}$, von Blanckenburg 1992) returned ages within $2 \%$ of the nominal value. Their suitability for allanite geochronology was recently confirmed by the extensive study of Smye et al. (2014). Allanite from Mont Morion granite is very similar in chemical composition to these standards, thus eliminating the issue of matrix effects (see also Gregory et al. 2007). Single ages were corrected for common $\mathrm{Pb}$ based on measured ${ }^{207} \mathrm{~Pb} /{ }^{206} \mathrm{~Pb}$ in a similar way to zircon, as described in Gregory et al. (2007). Common $\mathrm{Pb}$ measured in allanite is essentially inherent, therefore an estimate of initial $\mathrm{Pb}$ composition at the time of crystallisation from an evolving model $\mathrm{Pb}$ composition (Stacey and Kramers 1975) was assumed. Alternatively the ${ }^{207} \mathrm{~Pb} /{ }^{206} \mathrm{~Pb}$ of common $\mathrm{Pb}$ was obtained from a free regression in the total $\mathrm{Pb}$ Tera-Wasserburg diagram (Tera \& Wasserburg 1972). For both minerals, the data evaluation and age calculation were done using the software Squid (Squid 1 for zircon and Squid 2 for allanite) and Isoplot/Ex (Ludwig, 2003a, 2003b), respectively. Average ages are quoted at $95 \%$ confidence level (c.l.).

\subsection{Zircon laser ablation ICP-MS dating}

The samples were crushed to a grain size of $\sim 250 \mu \mathrm{m}$ using a SELFRAG instrument at the University of Bern. Zircons were then extracted by Frantz magnetic separation (I $>1.35 \mathrm{~A})$ and heavy-liquid separation of the non-magnetic fraction in diiodomethane $\left(\rho>3.32 \mathrm{~g} / \mathrm{cm}^{2}\right)$. Zircon grains between 64 and $250 \mu \mathrm{m}$ were handpicked and mounted in $0.5 \mathrm{~cm}$-thick epoxy blocks, which were polished to reveal core textures of the crystals. Zircon grains were imaged using a Zeiss Evo 50 scanning electron microscope (SEM) at the University of Bern in the backscattered electron (BSE) mode and under variable pressure conditions (VPSE), using a $20 \mathrm{kV}$ accelerating voltage, $\sim 1 \mathrm{nA}$ beam current and a working distance of $10 \mathrm{~mm}$.

Zircons were dated using an ELAN-DRCe ICPMS (Perkin Elmer, USA) coupled with a GeoLas Pro $193 \mathrm{~nm}$ ArF Excimer laser system (Lambda Physik, Germany) at the University of Bern. Before performing measurements, the different analytical conditions (including the gas flow rates, torch parameters, ion-lenses and acceleration voltages on the quadrupole) were optimised by ablation of a National Institute of Standards and Technology (NIST) standard reference glass SRM 610. The carrier gas consisted of a mixture of $\mathrm{He}(1.000 \mathrm{l} / \mathrm{min})$ and $\mathrm{H}_{2}(0.008 \mathrm{l} /$ $\mathrm{min})$, and was mixed with $\mathrm{Ar}(\mathrm{L} / \mathrm{min})$ prior to its introduction in the plasma. The $\mathrm{U}^{+} / \mathrm{Th}^{+}$intensity ratio for the NIST SRM 610 standard was c. $100 \%$. $\mathrm{ThO}^{+}, \mathrm{UO}^{+}$and $\mathrm{Ca}^{2+} / \mathrm{Ca}^{+}$ratios were $0.15-0.20,<0.10$ and $0.4-0.5 \%$, respectively. Laser operating conditions were: $4 \mathrm{~Hz}$ repetition rate, $5 \mathrm{~J} / \mathrm{cm}^{2}$ on-sample fluence, and spot sizes of 24 and $32 \mu \mathrm{m}$. The analytical list included the ${ }^{202} \mathrm{Hg},{ }^{204} \mathrm{~Pb}$, ${ }^{206} \mathrm{~Pb},{ }^{207} \mathrm{~Pb},{ }^{208} \mathrm{~Pb},{ }^{232} \mathrm{Th},{ }^{235} \mathrm{U},{ }^{238} \mathrm{U}$ isotopes of interest. The ${ }^{202} \mathrm{Hg}$ isotope allowed monitoring the isobaric overlap of ${ }^{204} \mathrm{Hg}$ on ${ }^{204} \mathrm{~Pb}$, using mass biased ratios. Dwell times per isotope ranged from 5 to $30 \mathrm{~ms}$. Peak hopping mode was employed, as well as dual (counting and analog) detector mode. Measurements were carried out in peak hopping mode (dwell times from 5 to $30 \mathrm{~ms}$ ) and dual 
(counting and analog) detector mode. Acquisition times for background and sample amounted to 55 and $40 \mathrm{~s}$, respectively. The Plešovice zircon (TIMS ${ }^{206} \mathrm{~Pb} /{ }^{238} \mathrm{U}$ age of $337.13 \pm 0.37 \mathrm{Ma}$; Sláma et al., 2008) was used for external standardisation and the GJ-1 zircon (TIMS ${ }^{207} \mathrm{~Pb} /{ }^{206} \mathrm{~Pb}$ age of $608.5 \pm 1.5 \mathrm{Ma}$; Jackson et al. 2004) served as secondary standard. Typical acquisition series consisted of 10-12 measurements of unknown zircons and 2 measurements of the Plešovice standard, bracketed at the start and end of each analytical sequence by two GJ-1 standard analyses.

Intensity vs. time data signals for isotopic $\mathrm{U}-\mathrm{Th}-\mathrm{Pb}$ data were reduced using an Excel spreadsheet (for calculation, see El Korh 2013) following the ratio-of-the mean intensity method (Ulianov et al. 2012). Intervals of 45 and $25 \mathrm{~s}$ were selected for the background and the ablation signal, respectively, with an offset of $5 \mathrm{~s}$ from the beginning of the ablation. Data spikes outside of two standard deviations of the mean signal value were corrected. Mean isotope intensity ratios $\left({ }^{206} \mathrm{~Pb} /{ }^{238} \mathrm{U},{ }^{207} \mathrm{~Pb} /{ }^{235} \mathrm{U}\right.$ and $\left.{ }^{207} \mathrm{~Pb} /{ }^{206} \mathrm{~Pb}\right)$ were calculated using background-corrected mean signal intensities. External standard measurement allowed calculating k-coefficients (concentration ratio/intensity ratio), employed to calculate sample concentration ratios that will be used to determine ages, assuming that $\mathrm{k}$ coefficients are the same for external standards and samples. Apparent ${ }^{206} \mathrm{~Pb} /{ }^{238} \mathrm{U}$ ages from $599 \pm 19$ to $608 \pm 22 \mathrm{Ma}$ (weighted average age $=601.6 \pm 6.0 \mathrm{Ma}(95 \%$ c.1.); $\mathrm{n}=9)$ were obtained for the GJ-1 zircon and are similar within uncertainty to the apparent TIMS ${ }^{206} \mathrm{~Pb} /{ }^{238} \mathrm{U}$ ages (596.2-602.7 Ma; wt. mean age: 600.38 Ma) presented in Jackson et al. (2004). No common lead correction was applied. Common $\mathrm{Pb}$ enrichments were monitored by a careful control of intensities acquired on masses 202 and 204, following the approach of Jackson et al. (2004). Concordia diagrams were generated using Isoplot v. 4.15 (Ludwig, 2003a, 2003b).

\subsection{Zircon trace element composition}

Trace element analyses were performed on zircons using the same quadrupole LA-ICPMS instrument. A mixture of He $(1.000 \mathrm{~L} / \mathrm{min})$ and $\mathrm{H}_{2}(0.008 \mathrm{~L} / \mathrm{min})$ was used as the cell gas. The $\mathrm{ThO}^{+} / \mathrm{Th}^{+}$and $\mathrm{UO}^{+} / \mathrm{U}^{+}$and $\mathrm{Ca}^{2+} / \mathrm{Ca}^{+}$ratios were adjusted to 0.2 and $0.4 \%$, respectively. Analyses were performed in spot mode, at $6 \mathrm{~J} / \mathrm{cm}^{2}$ on-sample fluence, $10 \mathrm{~Hz}$ repetition rate and $24-35 \mu \mathrm{m}$ pit sizes. Acquisition times for background and sample were c. 70 and 30-35 s, respectively. Signals were acquired in peak hopping mode (dwell times from 5 to $30 \mathrm{~ms}$ ) and dual (counting and analog) detector mode. The NIST SRM 612 reference glass was used for external standardisation, using the values from Pearce et al. (1997) and updated according to the
GeoReM database (http://georem.mpch-mainz.gwdg.de). ${ }^{29} \mathrm{Ca}$ served as an internal standard. Intensity vs. time data were reduced using SILLS, a MATLAB-based programme (Guillong et al., 2008). Intervals of 45 and $25 \mathrm{~s}$ were employed for the calculation of background and ablation intensity signals, respectively. Intensity spikes were corrected, when present.

\subsection{Whole-rock geochemistry}

Major and minor elements were determined in whole-rock samples by inductively coupled plasma atomic emission spectrometry (ICP-AES) at the SARM analytical facility of the Centre de Recherches Pétrographiques et Géochimiques (CRPG,-CNRS, Nancy, France) while incompatible trace elements were measured by ICP-MS. Bulk-rock glasses were fused at $980{ }^{\circ} \mathrm{C}$ by mixing appropriate proportions (1:5) of fine-grained rock powder with di-lithium tetraborate. Then, glasses were dissolved in a mixture of $\mathrm{HNO}_{3}(5 \%), \mathrm{H}_{2} \mathrm{O}_{2}(0.5 \%)$ and glycerol (10\%) prior to analysis. Details about the method used for the analyses are available in Carignan et al. (2001). Uncertainties at $1 \sigma$ are c. $5 \%$ and $8 \%$ for the ICP-AES and ICP-MS data, respectively.

\section{Petrography of samples}

In this study, three samples were investigated (Figs. 2a, 3b): (1) a biotite-bearing granite (\#J504, Mont Morion granite) and (2) two migmatitic biotite-bearing gneisses (\#R22 and \#R26).

\subsection{Mont Morion granite (\#J504)}

The Mont Morion granite \#J504 (UTM ED 1950 coordinates: 375082-5082529) was collected in the Comba de Crête Sèche, at the foot of Pointe Duc (Figs. 2, 3b). Sample \#J504 is medium to coarse grained and preserves its preAlpine igneous equigranular texture, consisting of quartz, red-brownish biotite and accessory allanite, apatite, zircon, and Fe-Ti oxides. Apatite and zircon frequently occur as inclusions in magmatic biotite, which is subhedral to euhedral, slab- or flake-shaped, forming aggregates. Biotite is frequently altered, displaying sagenitic exsolutions, and becoming paler or chloritized. Magmatic feldspar is not preserved, being altered to fine-grained sericite aggregates.

Sample \#J504 is weakly peraluminous $(\mathrm{A} / \mathrm{CNK}=1.06)$ and contains moderate total alkali content $\left(\mathrm{K}_{2} \mathrm{O}+\mathrm{Na}_{2}\right.$ $\mathrm{O}=7.52$; Tab. S2). It shows an enrichment in light REEs compared to heavy REEs, with $\mathrm{La}_{\mathrm{N}} / \mathrm{Yb}_{\mathrm{N}}$ ratios of 43 and a small negative $\mathrm{Eu}$ anomaly $\left(\mathrm{Eu} / \mathrm{Eu}^{*}=0.40\right)$. Trace element compositions show high $\mathrm{Ba}, \mathrm{Ga}, \mathrm{Zr}$. Zirconium 
concentration is relatively high (304 ppm) (Tab. S2). Zircon saturation thermometry (Boehnke et al. 2013) yields a temperature of $\sim 800^{\circ} \mathrm{C}$ for zircon crystallization in the melt.

\subsection{Migmatitic biotite-gneiss (\#R22, \#R26)}

Migmatitic gneisses \#R22 and \#R26 (\#R22 UTM ED 1950 coordinates: 375150-5082890, \#R26 UTM ED 1950 coordinates: 375105-5082685) (Fig. 5f), were both collected in the Comba de Crête Seche. \#R22 was sampled in the $2 \mathrm{~km}$ long body (interpreted as the country-rocks), at the foot of Pic de la Vierge, very close (within $1 \mathrm{~m}$ ) to the contact with the Mont Morion granite (Figs. 2 and 3b). \#R26 was sampled in a metre-scale lenticular body of migmatitic biotite-gneiss (i.e. xenolith) enclosed by the Mont Morion granite (Figs. 2 and 3).

Migmatitic biotite-gneiss shows a characteristic rustyorange weathering colour and a banded structure, defined by quartz-feldspar layers alternating with biotite seams. Biotite is frequently not strictly parallel to the banding, with crystals displaying different orientations. At handsample and micro-scale, coarse-grained quartz is more abundant in \#R26 (up to $\sim 30 \%$ ) than in \#R22 (up to $\sim 10 \%$ ).

The Ti content in biotite in \#R22 varies from 0.34 to 0.57 p.f.u., $\mathrm{X}_{\mathrm{Mg}}$ from 0.38 to 0.45 (Tab. S1), corresponding to a crystallization temperature of $668-741{ }^{\circ} \mathrm{C}$ $\left( \pm 12{ }^{\circ} \mathrm{C}\right.$, Henry et al. 2005). Such temperatures are above the experimentally-determined solidus for pelitic or semi-pelitic compositions (e.g., Thompson 1976; Le Breton and Thompson 1988; Vielzeuf and Holloway 1988; Thompson and Connolly 1995) and confirm that the rocks underwent partial melting. In \#R26, biotite is frequently sagenitic or replaced at the rim by chlorite and, for this reason, its Ti content could not be used to estimate temperature. Accessory zircon and apatite are dispersed in the rock. Very sparse ilmenite is found associated with biotite.

\section{Zoning, composition and U-Th-Pb geochronology of accessory phases}

Trace element composition and U-Th-Pb ages of allanite and zircon separated from the Mont Morion granite \#J504 were analysed by SHRIMP ion microprobe (Tabs S3 and S6). Chemical composition and U-Pb ages of zircon from the two migmatitic biotite-bearing gneiss (\#R22 and \#R26) were analysed by LA-ICP-MS (Tabs S7, S8). Internal zoning of zircon and allanite grains was investigated by cathodoluminescence and back-scattered electron imaging, respectively.
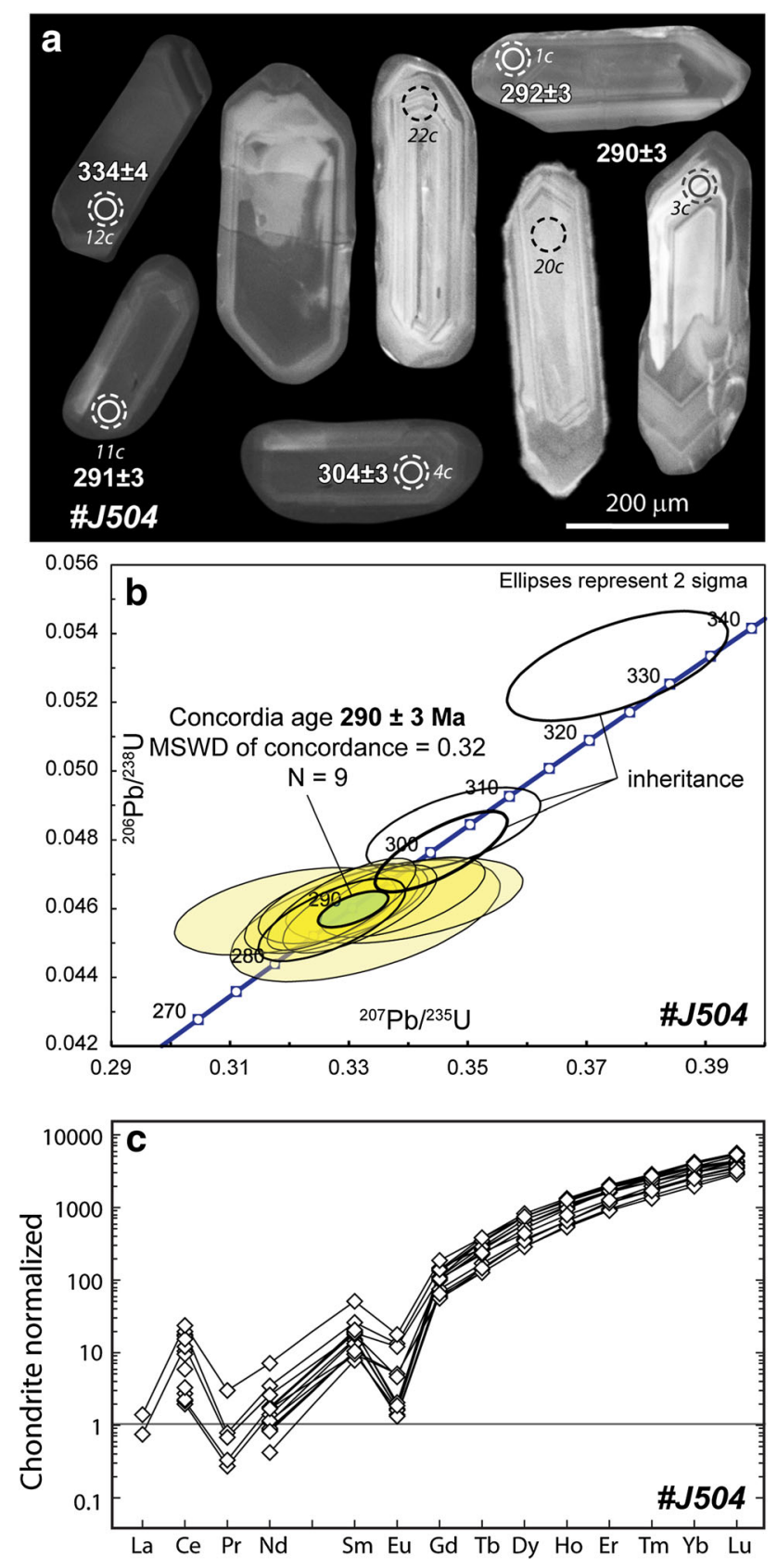

Fig. 6 a Cathodoluminescence images of zircon crystals from \#J504. Circles and dashed circles indicate the location of SHRIMP and trace element analyses, respectively. White and dashed white circles indicate SHRIMP (given as ${ }^{206} \mathrm{~Pb} /{ }^{238} \mathrm{U}$ ages) and trace elements analyses respectively. Labels refer to Tabs. S3 and S4; b Concordia diagram for zircon analyses for sample \#J504; empty ellipses represent data that were excluded form Concordia age calculation; c Zircon trace element composition from sample \#J504. REE patterns are normalized to chondrite values (Sun and McDonough, 1989)

\subsection{Mont Morion granite}

Zircon crystals from the Mont Morion granite (\#J504) are mainly dark pink, prismatic in shape with grain size up to $400 \mu \mathrm{m}$ (Fig. 6a). They show well-preserved oscillatory 

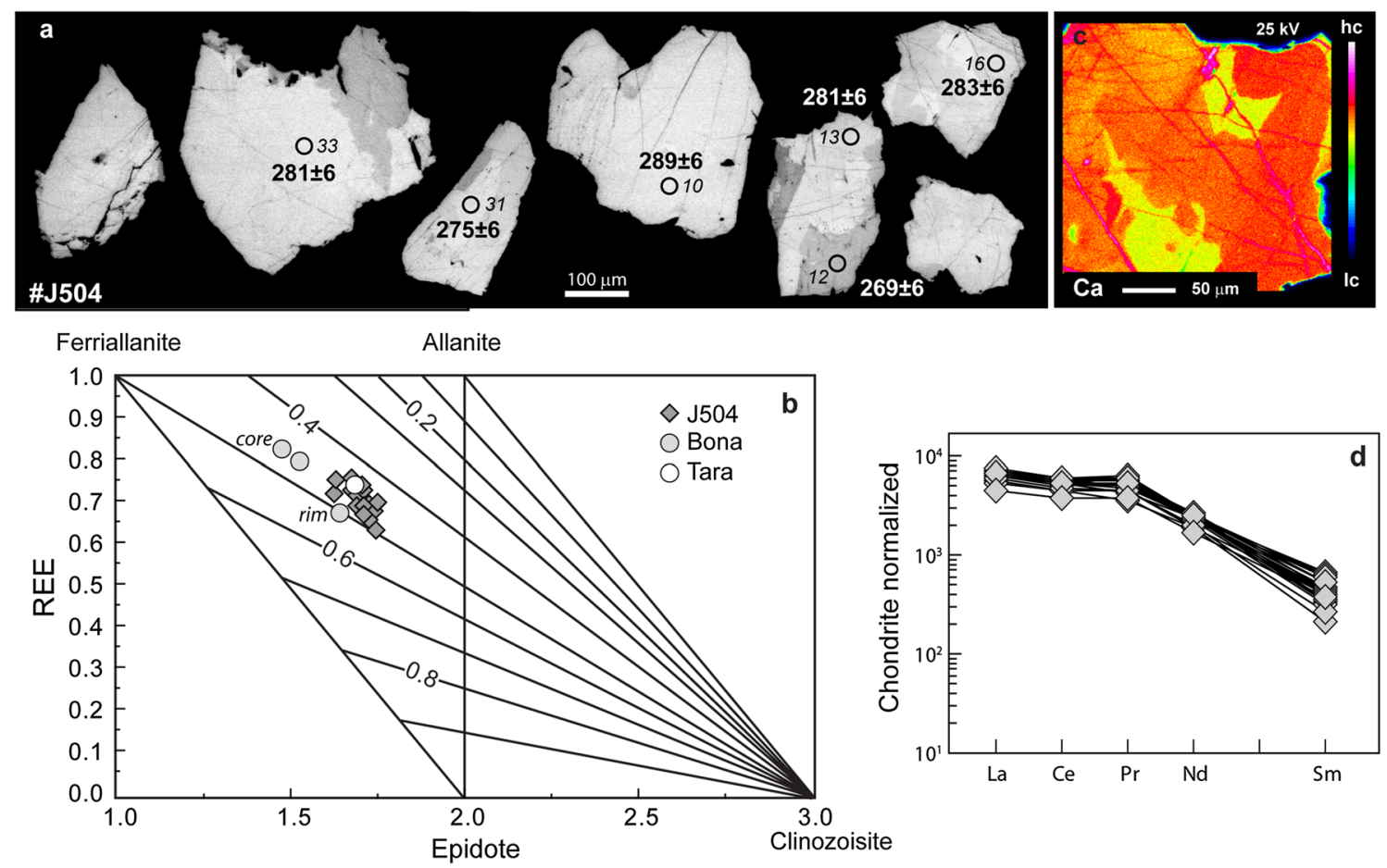

Al

Fig. 7 a BSE images of allanite crystals from granite \#J504. Black circles indicate the location of SHRIMP analyses plotted in Fig. 8. Labels refer to single spot SHRIMP analyses (given as ${ }^{206} \mathrm{~Pb} /{ }^{238} \mathrm{U}$ ages). Labels refer to Tabs. S6 and S7; b REE vs. Al (cation per formula unit) diagram showing the chemical relationships in the system allanite-ferriallanite-epidote-clinozoisite for \#J504 Petrík

growth zoning in $\mathrm{CL}$ images. U-Pb analyses from zircon have yield ${ }^{206} \mathrm{~Pb} /{ }^{238} \mathrm{U}$ dates ranging from $288 \pm 5 \mathrm{Ma}$ to $334 \pm 4 \mathrm{Ma}(1 \sigma)$. Most analyses (9 out of 12 ) define a concordia age of $290 \pm 3 \mathrm{Ma}(95 \%$ c.l.) with 3 analyses showing evidence of $\mathrm{Pb}$ inheritance (Fig. 6b, Tab. S3).

Chondrite-normalized REE patterns are similar for all zircon grains, with HREE enrichment, a positive $\mathrm{Ce}$ and negative Eu anomaly (Fig. 6c), and with relatively high $\mathrm{Th} /$ U (0.06-0.30; Tab. S4). The zircon REE patterns and internal zoning are typical of igneous zircon (e.g., Hoskin and Schaltegger 2003; Corfu 2003).

Magmatic allanite crystals are subhedral, brown and pleochroic, with dimensions varying from 100 to $500 \mu \mathrm{m}$ (Figs. 7a). Allanite is dominated by Ce over other LREE (e.g. La, Nd; Fig. 7b). The $\sum$ REE ranges from 0.464 to 0.745 p.f.u. (Table S5). In BSE images (Fig. 7a), the grains show some patchy zoning, reflecting variations in $\mathrm{Ca}$ (Fig. 7c). The decrease in $\mathrm{Ca}$ and $\mathrm{Al}$ is accompanied by an increase in $\mathrm{Fe}^{2+}$ and REE, following the typical allanite substitution: $\mathrm{Ca}^{2+}+\left(\mathrm{Al}, \mathrm{Fe}^{3+}\right)=\mathrm{REE}^{3+}+-$ $\mathrm{Fe}^{2+}$ (Deer et al. 2013). The decrease in $\mathrm{Ca}$ is coupled with an increase in $\mathrm{Mn}$, a feature observed in allanite from other granitoids (e.g., Hoshino et al. 2006). The analysed allanite grains show chondrite-normalized
(1995). Allanite compositions of the standards Tara and Bona are from Gregory et al. (2007) and Smye (2014), respectively; c Ca X-ray map of allanite from \#J504; d Plots of chondrite-normalized REE concentrations (as determined by electron microprobe analysis). Chondrite values are from Sun and McDonough (1989)

patterns for the LREE with rather flat La-Pr and a strong decrease in Sm (Fig. 7d).

In the Mont Morion granite \#J504, allanite grains have $\mathrm{Th} / \mathrm{U}$ between 20 and 66 . The $\mathrm{U}-\mathrm{Pb}$ system (Table S6) contains relatively high concentrations of initial $\mathrm{Pb}$ $(5-24 \%)$, whereas the $\mathrm{Th}-\mathrm{Pb}$ system is more radiogenic (1-6\% of initial ${ }^{208} \mathrm{~Pb}$ ). A regression on the Tera-Wasserburg (total $\mathrm{Pb}$ ) diagram (Fig. 8a), which makes no assumption on the composition of the initial $\mathrm{Pb}$, returns a lower intercept age of $291 \pm 6 \mathrm{Ma} \quad(95 \%$ c.l., MSWD $=0.64$ ), but with an unusual ${ }^{207} \mathrm{~Pb} /{ }^{206} \mathrm{~Pb}$ intercept of $1.44 \pm 0.46$, which is highly dependent on two analyses with higher common $\mathrm{Pb}$. Assuming a model for common $\mathrm{Pb}$ composition ( $\sim 0.854$, Stacey and Kramers 1975) at $280 \mathrm{Ma}$, the U-Pb and $\mathrm{Th}-\mathrm{Pb}$ system return identical ages of $280 \pm 8 \mathrm{Ma} \quad(95 \% \quad$ c.l., $\quad$ MSWD =0.14) $\quad$ and $280 \pm 7 \mathrm{Ma} \quad(95 \% \quad$ c.l., $\quad$ MSWD $=0.37, \quad$ Fig. $8 b)$, respectively.

\subsection{Migmatitic biotite-bearing gneiss}

Both migmatitic biotite gneisses have abundant zircon with grain size up to $150 \mu \mathrm{m}$ (\#R22) and $200 \mu \mathrm{m}$ (\#R26). \#R22 contains prismatic zircon grains, preserving relatively 

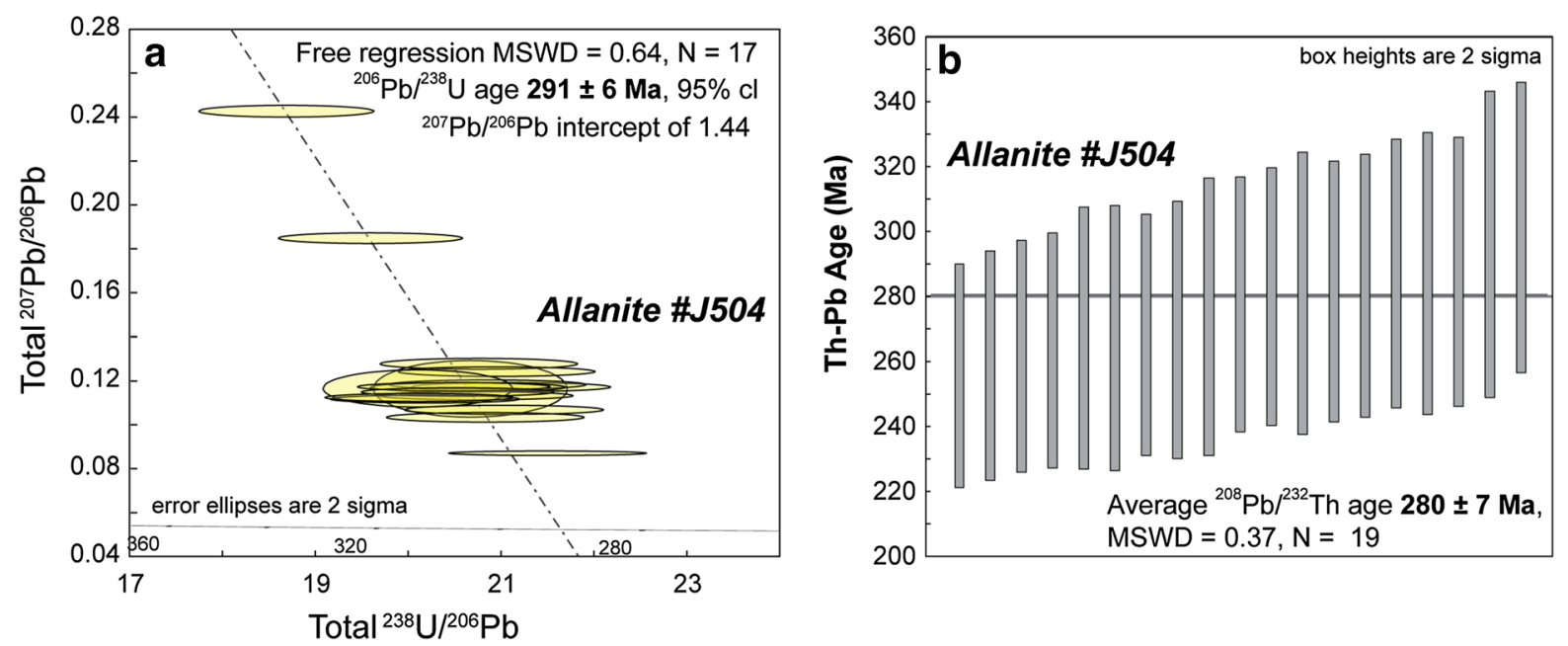

Fig. 8 a Tera-Wassenburg plot of allanite analyses (not corrected for common $\mathrm{Pb}$ ) from sample \#J504. Note that the common ${ }^{207} \mathrm{~Pb} /{ }^{206} \mathrm{~Pb}$ intercept is unusually high, see text for discussion; b Average Th-Pb age for the same analyses from sample \#J504. The average Th age is preferred, see text for discussion

small, rounded cores overgrown by rims that shows weak or not CL-zoning (Fig. 9a). \#R26 has prismatic zircons with large rounded cores that in most crystals are overgrown by a euhedral rim with weak CL-zoning (Fig. 9b). In both samples, the internal textures of the cores are diverse, but oscillatory zoning is the most common zoning type. The zoning patterns of these cores are truncated by the rim, suggesting that the zircon cores are detrital and underwent abrasion or dissolution before the rim formed. No mineral inclusions were found in zircon cores or rims.

Zircon cores in \#R22 have not been analysed due to their small sizes. $U$ and Th concentrations in \#R22 zircon rims range between 555 and $1356 \mathrm{ppm}$ and $59-148 \mathrm{ppm}$, respectively, with $\mathrm{Th} / \mathrm{U}$ ratios between 0.09 and 0.15 (Tab. S7). U-Pb analyses from overgrowths yield ${ }^{206} \mathrm{~Pb} /{ }^{238} \mathrm{U}$ dates ranging from $283.2 \pm 8.8$ to $290.9 \pm 9.2 \mathrm{Ma}(2 \sigma)$ with a weighted average of $285.2 \pm 2.9 \mathrm{Ma}(95 \%$ c.l.; $\mathrm{n}=8$, MSWD $=0.29$; Fig. S1a). U-Pb data form a cluster on the Concordia curves that defines a concordia age of $285.3 \pm 3.3 \mathrm{Ma}(2 \sigma ; \mathrm{n}=6$; MSWD $=0.27$; Fig. $9 \mathrm{c})$ for the six concordant analyses. In \#R26, zircon cores display variable $\mathrm{U}$ and $\mathrm{Th}$ contents $(35<\mathrm{U}<1514 \mathrm{ppm}$; $16<\mathrm{Th}<409 \mathrm{ppm})$ with ${ }^{206} \mathrm{~Pb} /{ }^{238} \mathrm{U}$ dates scattering between $3203 \pm 106$ to $453 \pm 15 \mathrm{Ma}$ (Tab. S7), in line with a detrital origin. $U$ and $\mathrm{Th}$ concentrations in overgrowths range between 819 and $1841 \mathrm{ppm}$ and 52-203 ppm respectively, with $\mathrm{Th} / \mathrm{U}$ ratios between 0.06 and $0.15 .{ }^{206} \mathrm{~Pb} /{ }^{238} \mathrm{U}$ dates for zircon rims range from $276 \pm 10 \mathrm{Ma}$ to $345 \pm 16 \mathrm{Ma}(2 \sigma)$. The younger zircon rims have a weighted average of $281.0 \pm 3.7 \mathrm{Ma}(95 \%$ c.l.; $\mathrm{n}=8$, MSWD $=0.277$; Fig. S1b), while the concordant points yield a Concordia age of $280.5 \pm 3.7 \mathrm{Ma}(2 \sigma$; $\mathrm{n}=7$; MSWD = 0.34) (Fig. 9d).
In both samples the Permian rims are enriched in HREE with respect to the MREE (Fig. 9e-f), as indicated by the high $\mathrm{Lu}_{N} / \mathrm{Sm}_{\mathrm{N}}$ ratios (353-705 for \#R26, 301-535 for \#R22). The negative Eu anomaly of the zircon is strong in both samples $\left(\mathrm{Eu} / \mathrm{Eu}^{*}\right.$ between 0.02 and 0.23 for \#R26, 0.02-0.07 for \#R22).

\section{Discussion}

\subsection{Age of intrusion of the Mont Morion granite}

The Mont Morion granite largely preserves its igneous texture and mineral content. There is a priori no reason for zircon to be modified after the granite crystallisation. Indeed, the shape and the internal texture of zircon suggest that it crystallizes in a magma, and that no significant modification has taken place during the subsequent history. In addition, the typical HREE enriched REE pattern and the negative Eu-anomaly of the zircon is in line with zircon crystallization from an evolved melt that already crystallized plagioclase (e.g., Hoskin and Schaltegger 2003). The absence of significant zircon inheritance (i.e., Early Palaeozoic or Proterozoic ages) in the Mont Morion granite suggests an initially zircon undersaturated melt composition for the magma. Therefore, the calculated zircon saturation temperature of $\sim 800{ }^{\circ} \mathrm{C}$ is taken as the maximum magma temperature (Miller et al. 2003). This temperature is compatible with crustal contamination of a fractionating mantle magma, as suggested for other Permian granitoids in the Alpine region (Schaltegger and Brack 2007 and references therein). The $\mathrm{U}-\mathrm{Pb}$ age $(290 \pm 3 \mathrm{Ma})$ of zircon obtained 

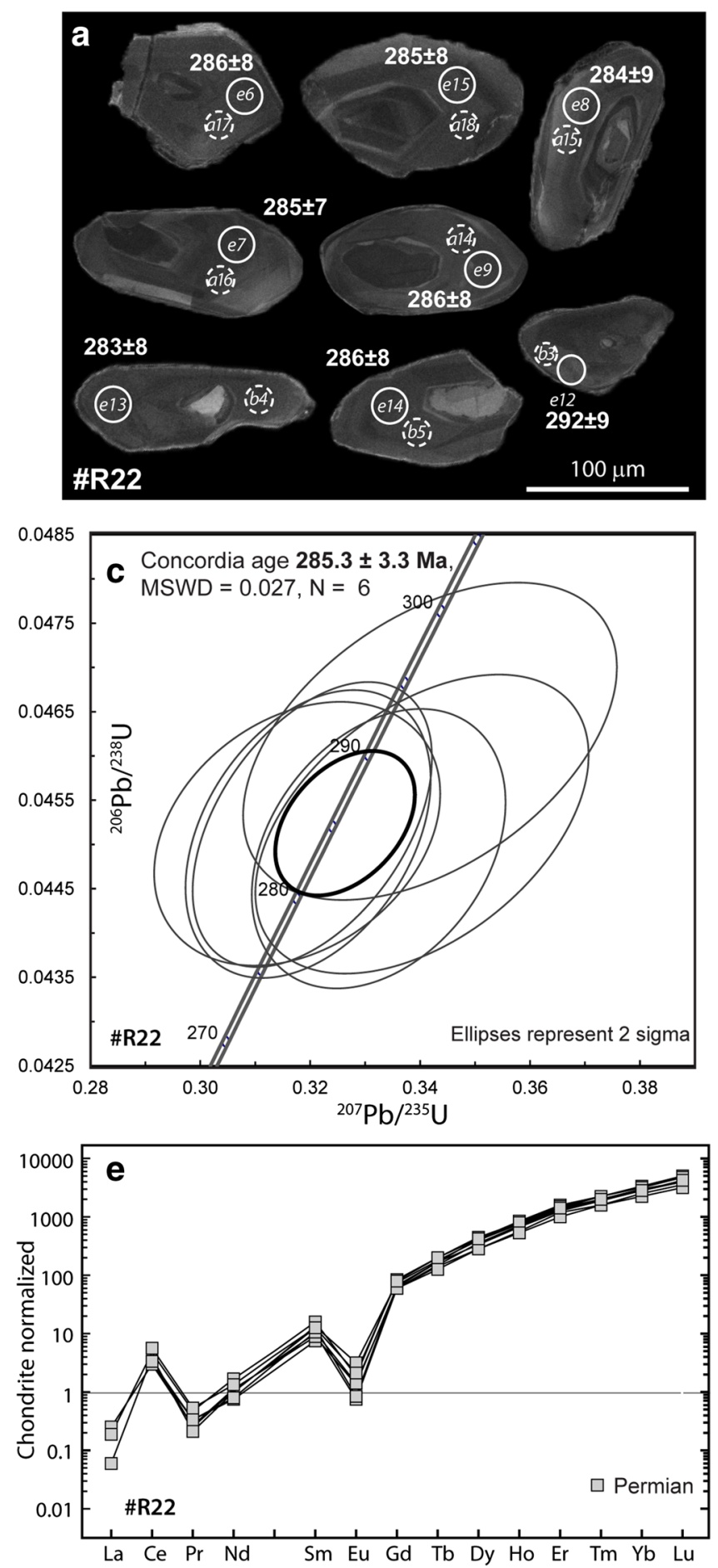

Fig. 9 a, b Cathodoluminescence images of zircon crystals from gneisses \#R22 and \#R26. White and dashed white circles indicate LAICP-MS (given as ${ }^{206} \mathrm{~Pb} /{ }^{238} \mathrm{U}$ ages) and trace elements analyses, respectively. Labels refer to Tabs. S7 and S8; c, d Zircon U-Pb

in this study is therefore considered as recording the early stages of crystallization of the magma. Few grains display slightly older concordant ages, at c. 300 and c. $330 \mathrm{Ma}$. These may represent grains incorporated into
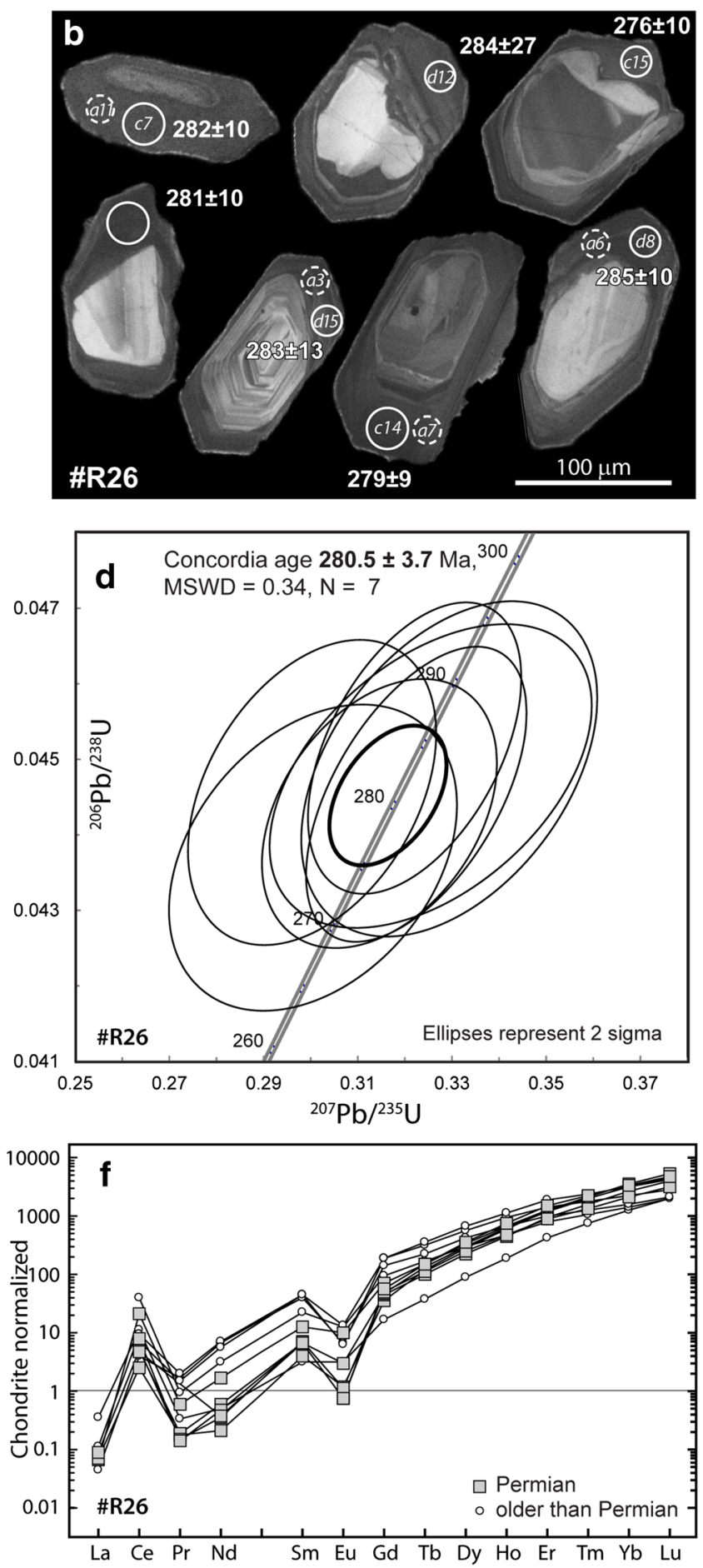

Concordia plots for the biotite-bearing gneiss e, f Zircon trace element composition. REE patterns are normalized to chondrite values (Sun and McDonough 1989)

the magma from an older partially melted source. Gneissic country-rocks of the Mont Morion granite might be seen as potential candidates for such a source, but our zircon data (see below) do not support this 
interpretation. The required source for the older zircons should be present in the lower crust rather than at the level of granite emplacement.

Allanite grains show patchy zoning, although core and rim compositions are similar and display small variations by comparison with other allanite in granitoid rocks (e.g. Oberli et al. 2004). The high REE content, high Th/U ratio, and the relatively low common $\mathrm{Pb}$ contents, at least in the Th system, argue for magmatic origin of the dated allanite (Oberli et al. 2004; Gregory et al. 2012). The U-Pb and $\mathrm{Th}-\mathrm{Pb}$ ages of allanite are identical (U-Pb: $280 \pm 8 \mathrm{Ma}$; Th- $\mathrm{Pb}: 280 \pm 7 \mathrm{Ma}$ ). The closure temperature of allanite is at least $700{ }^{\circ} \mathrm{C}$ (Oberli et al. 2004), and zircon saturation temperatures indicate that the Mont Morion granite crystallized at $\sim 800{ }^{\circ} \mathrm{C}$. Therefore the $280 \pm 7 \mathrm{Ma}$ age is interpreted as dating an early cooling stage, but prior to the final crystallization of this granite.

\subsection{P-T conditions and timing of partial melting in the country rocks of the Mont Morion granite}

Determining the $P-T$ conditions of the metamorphism in the migmatitic biotite-gneiss is a difficult task owing to its bulk-rock composition and thus the lack of diagnostic mineral assemblages. The Ti content in biotite (Henry et al. 2005) indicates amphibolite-facies conditions $\left(\sim 670-740{ }^{\circ} \mathrm{C}\right)$. Mineral assemblages are consistent with this statement. Specifically, peritectic minerals (e.g., garnet, cordierite and orthopyroxene) have not been observed in the leucosomes. In addition, garnet and rutile are very rare in these rocks (Roda and Zucali 2008; Dal Piaz et al. 2015) and they are not present in the samples studied. Finally, metamorphic zircon overgrowths (Figs. 9e, f) have steep REE-patterns that also indicate growth in a garnetfree assemblage, while the presence of plagioclase is evident from the moderate negative Eu-anomaly (similar to zircon in amphibolite-facies migmatites from the Central Alps, Rubatto et al. 2009). Garnet and orthopyroxene also have never been found in the amphibolite, either reflecting their bulk-rock compositions or low pressure metamorphic conditions. Therefore we suggest that the country-rocks reached partial melting at amphibolite-facies conditions, in contrast with granulite-facies conditions in the Valpelline Series (Gardien et al. 1994; Manzotti and Zucali 2013). Consequently, the country-rocks of the Mont Morion granite were located at mid crustal levels during pluton emplacement and do not represent lower crustal material.

Geochronological data are needed to estimate the precise timing of the partial melting in the country-rocks of the Mont Morion granite. Zircons separated from two samples of migmatitic biotite-gneiss (one found as xenolith and the other one as country-rock, see Fig. 2) include grains with detrital cores surrounded by one rim. Detrital

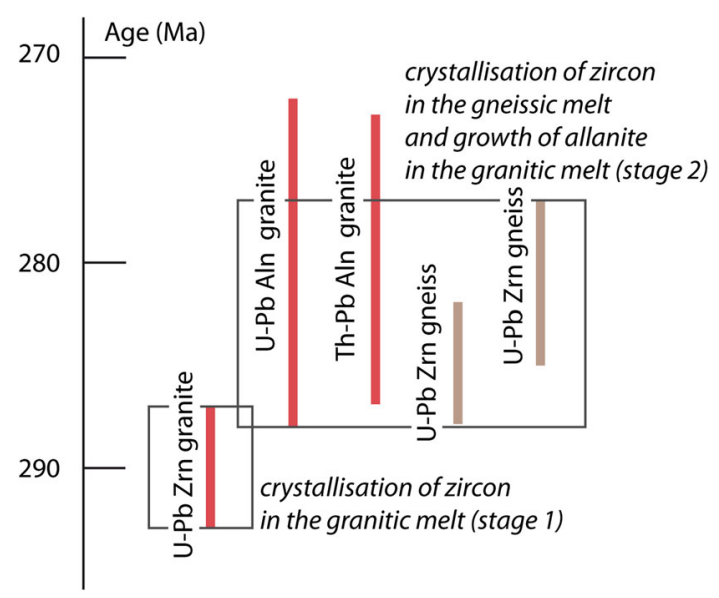

Fig. 10 Time constraints on the evolution of the Mont Morion granite and its country-rocks, based on the geochronological data obtained in this study

cores yielded Palaeoproterozoic to Palaeozoic (Ordovician) ages, no concordant Carboniferous ages have been found. The zircons rims are characterised by euhedral shape, weak internal zoning, moderate to low $\mathrm{Th} / \mathrm{U}(0.15-0.06)$ that are in line with growth during partial melting of felsic rocks (e.g., Vavra et al. 1999; Rubatto et al. 2001; Rubatto et al. 2009). Therefore the zircon rims are interpreted as dating migmatisation during Permian (\#R26: $281 \pm 4 \mathrm{Ma}$, \#R22: $285 \pm 3 \mathrm{Ma})$.

\subsection{Relationship between Permian magmatism and metamorphism in the DBTS}

The DBTS is a large composite thrust sheet, composed of slices of upper to middle (e.g. Arolla Series) and lower (e.g. Valpelline Series) continental crust (e.g. Argand 1911; Diehl et al. 1952; Dal Piaz et al. 1972, 2015; Manzotti et al. 2014a). Such slices now constitute different tectonic subunits bounded by Alpine shear zones, but they pervasively record the Permian metamorphic and magmatic history.

In the Arolla Series, migmatitic biotite-gneiss and amphibolite from the Mont Morion Unit constitute the sole occurrence known so far of pre-Permian basement (Burri et al. 1999; Dal Piaz et al. 2015). Field data show that the Mont Morion granite intruded partially melted gneiss and amphibolite, and that these country-rocks were still at high temperature at the time of its intrusion. Therefore, it is not surprising that the ages of the partial melting and the granite are similar within errors (c. 290-280 Ma). However, zircon ages from the granite are slightly older than the allanite ages from the granite as well as than the zircon ages from the migmatitic biotite gneiss, and this deserves a more detailed discussion. One potential explanation would be to consider a two-stage history (Fig. 10). In a first stage, 
zircon from the granite would have crystallised during the early cooling of the magma (i.e. ca. $800{ }^{\circ} \mathrm{C}$ ), before its final emplacement. In a second stage, crystallisation of melt in the gneissic country rock is likely to have occurred slightly before the intrusion of the Mont Morion granite, possibly while allanite grew from remaining melt.

The granitoid body and its country-rocks were at similar temperatures during granite emplacement, allowing ductile deformation of their interface. The absence of contact metamorphism around the Mont Morion granite (i.e., welldeveloped hornfelses with granoblastic textures) is consistent with this model, the country rocks being still partially molten during the emplacement of the Mont Morion granite.

In the Valpelline Series, Permian amphibolite to granulite facies regional metamorphism $(\sim 7-8 \mathrm{kbar}, 700$ to $850{ }^{\circ} \mathrm{C}$; e.g. Manzotti and Zucali 2013) is widely preserved. For this high temperature regional metamorphism, a bimodal age distribution of 287-283 Ma and 277-260 Ma has been recognized based on two distinct growth periods of metamorphic zircon, separated by an interval of $\sim 10-20 \mathrm{Ma}$ (Kunz et al. 2017). The first age group is contemporaneous with the main granitic and gabbroic intrusions in the DBTS (Dal Piaz et al. 1977; Monjoie et al. 2005; Manzotti et al. 2017; this study).

Overall, a clear temporal link between mantle melts underplating at the base of the crust, partial melting within the lower crust, and intrusions of granitic and gabbroic bodies at higher levels are recognized during Permian times in the DBTS. This evolution is closely similar to the one established for the Ivrea Verbano Zone (e.g. Rivalenti et al. 1975; Schnetger 1994; Klötzli et al. 2014). No evidence for a Triassic thermal imprint with associated (mantle-derived) magmatism is documented in the DBTS, whereas this is observed in the Southern Alps (e.g. Zanetti et al. 2013; Langone and Tiepolo 2015).

\section{Conclusions}

1. The Mont Morion Unit in the DBTS exposes large volumes that escaped Alpine deformation. These allow the reconstruction of several stages of the pre-Alpine magmatic and metamorphic evolution. Two plutons are identified, now separated by a ductile shear zone: the Aroletta amphibole-bearing granite and the Mont Morion biotite-bearing granite. The latter intruded partially-melted gneissic country-rocks, and the contact is deformed by syn-magmatic, ductile folds, suggesting magma emplacement during early stages of cooling of the migmatitic country-rocks.

2. The Permian age of the Mont Morion granite is constrained by $\mathrm{U}-\mathrm{Pb}$ data on zircon $(290 \pm 3 \mathrm{Ma})$ and allanite $(280 \pm 7 \mathrm{Ma})$. Migmatitic biotite-gneiss and amphibolite from the country rocks of the Mont Morion granite record partial melting at amphibolite facies conditions $\left(670-740{ }^{\circ} \mathrm{C}\right)$, dated at $280-290 \mathrm{Ma}$, i.e., virtually coeval with the Mont Morion intrusion. A slight difference in age between zircon from the granite and the country-rocks may indicate a prolonged history for the magmatic body, with an initial cooling at ca. $290 \mathrm{Ma}$ followed by final emplacement at ca. $285 \mathrm{Ma}$.

3. The DBTS records the high heat flow that affected the Adriatic margin in Permian times. This high thermal regime is linked to extensive partial melting, with migmatites and pegmatite dykes at lower crustal levels (e.g., Valpelline Series), and acid and basic intrusions at the higher levels (e.g., granitoids and gabbros forming the Arolla Series).

Acknowledgements Samples \#J504, \#R22, and \#R26 were collected during the MSc studies of G. Giordano, M. Roda, and R. Splendore, under the direction of M. Zucali. Financial support from the Swiss National Science Foundation (Projects PZ00P2_161202, 200020-126946 and -146175) is acknowledged. We appreciate the constructive reviews by U. Klötzli and G. Mohn. E. Gnos is thanked for editorial handling. This paper is dedicated to Gino Buscaini and Silvia Metzeltin, who nicely summarized in the "Guida dei Monti d'Italia" the geology of the Aroletta ridge following their alpinistic exploration.

\section{References}

Angiboust, S., Glodny, J., Oncken, O., \& Chopin, C. (2014). In search of transient subduction interfaces in the Western Alps subduction system. Lithos, 205, 298-321.

Argand, E. (1911). L'exploration géologique des Alpes Pennines Centrales. Bulletin des Laboratoires de Géologie de l'Université de Lausanne, 14, 1-64.

Armstrong, J. T. (1988). Quantitative analysis of silicate and oxide materials: Comparison of Monte Carlo. In D. E. Newbury (Ed.), $Z A F$ and $j(r Z)$ procedures, microbeam analysis (pp. 239-246). San Francisco: San Francisco Press.

Armstrong, J. T. (1991). Quantitative elemental analysis of individual microparticles with electron beam instruments. In K. F. S. Heinrich \& D. E. Newbury (Eds.), Electron probe quantitation (pp. 261-315). New York: Plenum Press.

Ayrton, S., Bugnon, C., Haarpainter, T., Weidmann, M., \& Frank, E. (1982). Géologie du front de la nappe de la Dent Blanche dans la région des Monts-Dolins, Valais. Eclogae Geologicae Helvetiae, $75,269-286$.

Baletti, L., Zanoni, D., Spalla, M. I., \& Gosso, G. (2012). Structural and petrographic map of the Sassa gabbro complex (Dent Blanche nappe, Austroalpine tectonic system, Western Alps, Italy). Journal of Maps, 8, 413-430.

Black, L. P., Kamo, S. L., Allen, C. M., Aleinikoff, J. N., Davis, D. W., Korsch, R. J., et al. (2003). TEMORA 1: a new zircon standard for Phanerozoic U-Pb geochronology. Chemical Geology, 200, 155-170. 
Boehnke, P., Watson, E. B., Trail, D., Harrison, T. M., \& Schmitt, A. K. (2013). Zircon saturation re-visited. Chemical Geology, 351, 324-334.

Burri, M., Dal Piaz, G. V., Della Valle, G., Gouffon, Y., \& Guermani, A. (1999). Feuille 1346 Chanrion, avec partie nord de la feuille 1366 Mont Vélan (p. 101). Notice explicative: Atlas géologique de la Suisse.

Bussy, F., Venturini, G., Hunziker, J. C., \& Martinotti, G. (1998). $\mathrm{U}-\mathrm{Pb}$ ages of magmatic rocks of the Western Austroalpine DentBlanche-Sesia Unit. Schweizerische Mineralogische und Petrographische Mitteilungen, 78, 163-168.

Carignan, J., Hild, P., Mevelle, G., Morel, J., \& Yeghicheyan, D. (2001). Routine analyses of trace elements in geological samples using flow injection and low pressure on-line liquid chromatography coupled to ICP-MS: a study of geochemical reference materials, BR, DR-N, UB-N, AN-G and GH. Geostandards Newsletters, 25, 187-198.

Carraro, F., Dal Piaz, G. V., \& Sacchi, R. (1970). Serie di Valpelline e II Zona Diorito-Kinzigitica sono i relitti di un ricoprimento proveniente dalla zona Ivrea-Verbano. Memorie della Società Geologica Italiana, 9, 197-224.

Cenki-Tok, B., Oliot, E., Rubatto, D., Berger, A., Engi, M., Janots, E., et al. (2011). Preservation of Permian allanite within an Alpine eclogite facies shear zone at Mt Mucrone, Italy: mechanical and chemical behavior of allanite during mylonitization. Lithos, 125, $40-50$.

Compagnoni, R. (1977). The Sesia-Lanzo Zone: high pressure-low temperature metamorphsim in the Austroalpine continental margin. Rendiconti Società Italiana di Mineralogia e Petrologia, 33, 335-374

Corfu, F., Hanchar, J. M., Hoskin, P. W. O., \& Kinny, P. (2003). Atlas of zircon textures. In J. M. Hanchar \& P. W. O. Hoskin (Eds.), zircon (53rd ed., pp. 469-500). Washington: Mineralogical Society of America.

Dal Piaz, G. V. (1997). Geology of the Matterhorn and surroundings. Quaderni di Geodinamica Alpina e Quaternaria, 4, 36-37.

Dal Piaz, G. V., \& Martin, S. (1988). Evoluzione litosferica e magmatismo nel dominio austro-sudalpino dall'orogenesi varisica al rifting permo-mesozoico. Memorie della Società Geologica Italiana, 53, 43-62.

Dal Piaz, G. V., Hunziker, J. C., \& Martinotti, G. (1972). La Zona Sesia-Lanzo e l'evoluzione tettonico-metamorfica delle Alpi nordoccidentali interne. Memorie della Società Geologica Italiana, 11, 433-466.

Dal Piaz, G. V., De Vecchi, G., \& Hunziker, J. C. (1977). The Austroalpine layered gabbros of the Matterhorn and Mt. CollonDents de Bertol. Schweizerische Mineralogische und Petrographische Mitteilungen, 57, 59-88.

Dal Piaz, G. V. (1993). Evolution of Austro-Alpine and Upper Penninic basement in the northwestern Alps from Variscan convergence to post-Variscan extension. In J. F. von Raumer \& F. Neubauer (Eds.), Pre-mesozoic geology in the alps (pp. 327-344). Berlin: Springer.

Dal Piaz, G. V., Gianotti, F., Monopoli, B., Pennacchioni, G., Tartarotti, P., \& Schiavo, A. (2010). Note illustrative della Carta Geologica d'Italia alla scala 1:50.000, Foglio 091, Chatillon. Servizio Geologico d'Italia, 091, 5-152.

Dal Piaz, G. V., Bistacchi, A., Gianotti, F., Monopoli, B., \& Passeri, L. (2015). Note illustrative della carta Geologica d'Italia alla scala 1:50000. Foglio 070, Cervino. Servizio Geologico d'Italia, 070, 1-431.

Deer, W. A., Howie, R. A., \& Zussman, J. (2013). An introduction to the rock-forming minerals (3rd ed.) (pp. 498). Mineralogical Society of Great Britain and Ireland, London

Didier, J., \& Barbarin, B. (1991). Enclaves and granite petrology $(625 \mathrm{pp})$. Amsterdam-Oxford-New York-Tokyo: Elsevier.
Diehl, E. A., Masson, R., \& Stutz, A. H. (1952). Contributo alla conoscenza del ricoprimento della Dent Blanche. Memorie degli Istituti di Geologia e Mineralogia dell'Università di Padova, 17, $1-52$.

Diella, V., Spalla, M. I., \& Tunesi, A. (1992). Contrasting thermomechanical evolutions in the Southalpine metamorphic basement of the Orobic Alps (Central Alps, Italy). Journal of Metamorphic Geology, 10, 203-219.

El Korh, A. (2013). Ablation behaviour and constraints on the U-Pb and $\mathrm{Th}-\mathrm{Pb}$ geochronometers in titanite analysed by quadrupole LA-ICP-MS coupled to a $193 \mathrm{~nm}$ excimer laser. Spectrochimica Acta part B, 86, 75-87.

Gardien, V., Reusser, E., \& Marquer, D. (1994). Pre-Alpine metamorphic evolution of the gneisses from Valpelline series (Western Alps, Italy). Schweizerische Mineralogische und Petrographische Mitteilungen, 74, 489-502.

Gregory, C. J., Rubatto, D., Allen, C. M., Williams, I. S., Hermann, J., \& Ireland, T. (2007). Allanite micro-geocrhonology: a SHRIMP and LA-ICP-MS study. Chemical Geology, 245, 162-182.

Gregory, C., Rubatto, D., Hermann, J., Berger, A., \& Engi, M. (2012). Allanite behaviour during incipient melting in the southern Central Alps. Geochimica et Cosmochimica Acta, 84, 433-458.

Guillong, M., Meier, D. M., Allan, M. M., Heinrich, C. A., \& Yardley, B. (2008). SILLS: a MATLAB-based program for the reduction of laser ablation ICP-MS data of homogeneous materials and inclusions (pp. 328-333). Québec: Mineralogical Association of Canada.

Handy, M. R., Schmid, S. M., Bousquet, R., Kissling, E., \& Bernoulli, D. (2010). Reconciling plate-tectonic reconstructions of Alpie Tethys with the geological-geophysical record of spreading and subduction in the Alps. Earth-Science Reviews, 102, 121-168.

Henry, B., Guidotti, C. V., \& Thomson, J. A. (2005). The Tisaturation surface for low-to-medium pressure metapelitic biotite: implications for geothermometry and Ti-substitution mechanisms. American Mineralogist, 90, 316-328.

Hoskin, P. W. O., \& Schaltegger, U. (2003). The composition of zircon and igneous and metamorphic petrogenesis. In $\mathrm{J}$. M. Hanchar \& P. W. O. Hoskin (Eds.), zircon (53rd ed., pp. 27-62). Washington: Mineralogical Society of America.

Hoshino, M., Kimata, M., Shimizu, M., Nishida, N., \& Fujiwara, T. (2006). Allanite-(Ce) in granitic rocks from Japan: genetic implications of patterns of REE and Mn enrichment. The Canadian Mineralogist, 44, 45-62.

Jackson, S. E., Pearson, N. J., Griffin, W. L., \& Belousova, E. A. (2004). The application of laser ablation-inductively coupled plasma-mass spectrometry to in situ U-Pb zircon geochronology. Chemical Geology, 211, 47-69.

Janots, E., Engi, M., Berger, A., Allaz, J., Schwarz, J.-O., \& Spandler, C. (2008). Prograde metamorphic sequence of REE minerals in pelitic rocks of the Central Alps: implications for allanitemonazite-xenotime phase relations from 250 to $610{ }^{\circ} \mathrm{C}$. Journal of Metamorphic Geology, 26, 509-526.

Kiénast, J., \& Nicot, E. (1971). Présence d'une paragenèse à disthène et chloritö̈de (d'âge alpin probable) dans les gneiss à sillimanite, grenat et cordiérite de Valpelline (Val d'Aoste, Italie) (pp. 1836-1840). Paris: Comptes Rendus de l'Académie des Sciences de Paris.

Klötzli, U. S., Sinigoi, S., Quick, J. E., Demarchi, G., Tassinari, C. C., Sato, K., et al. (2014). Duration of igneous activity in the Sesia Magmatic System and implications for the high-temperature metamorphism in the Ivrea-Verbano deep crust. Lithos, 206-207, 19-33.

Kunz, B. E., Manzotti, P., von Niederhäusern, B., Engi, M., Giuntoli, M., \& Lanari, P. (2017). Permian high-temperature metamorphism in the Western Alps (NW Italy). International Journal of Earth Sciences. doi:10.1007/s00531-017-1485-6. 
Langone, A., \& Tiepolo, M. (2015). U-Th-Pb “multi-phase" approach to the study of crystalline basement: application to the northernmost sector of the Ivrea-Verbano Zone (Alps). Periodico di Mineralogia, 84, 633-655.

Lardeaux, J. M., \& Spalla, M. I. (1991). From granulites to eclogites in the Sesia zone (Italian Western Alps): a record of the opening and closure of the Piedmont ocean. Journal of Metamorphic Geology, 9, 35-59.

Le Breton, N., \& Thompson, B. (1988). Contributions to Mineralogy and Petrology, 99, 226-237.

Ludwig, K. R. (2003a). Isoplot/Ex version 3.0. geochronological toolkit for Microsoft Excel Geochr (p. 70). Berkeley: A Centre Special Publication.

Ludwig, K.R. (2003b). User's manual for Isoplot 3.00: a geochronological toolkit for Microsoft excel.

Manzotti, P. (2011). Petro-structural map of the Dent Blanche tectonic system between Valpelline and Valtournenche valleys, Western Italian Alps. Journal of Maps, 7, 340-352.

Manzotti, P., Rubatto, D., Darling, J., Zucali, M., Cenki-Tok, B., \& Engi, M. (2012). From Permo-Triassic lithospheric thinning to Jurassic rifting at the Adriatic margin: petrological and geochronological record in Valtournenche (Western Italian Alps). Lithos, 146-147, 276-292.

Manzotti, P., \& Zucali, M. (2013). The pre-Alpine tectonic history of the Austroalpine continental basement in the Valpelline unit (Western Italian Alps). Geological Magazine, 150, 153-172.

Manzotti, P., Zucali, M., Ballèvre, M., Robyr, M., \& Engi, M. (2014a). The tectonometamorphic evolution of the Sesia-Dent Blanche nappes (internal Western Alps): review and synthesis. Swiss Journal of Geosciences, 107, 309-336.

Manzotti, P., Zucali, M., Ballèvre, M., Robyr, M., \& Engi, M. (2014b). Geometry and kinematics of the Roisan-Cignana Shear Zone, and the evolution of the Dent Blanche Tectonic System (Western Alps). Swiss Journal of Geosciences, 107, 23-47.

Manzotti, P., Ballèvre, M., \& Dal Piaz, G. V. (2017). Continental gabbros in the Dent Blanche Tectonic System (Western Alps): from the pre-Alpine crustal structure of the Adriatic palaeo-margin to the geometry of an alleged subduction interface. Journal of the Geological Society, London,. doi:10.1144/jgs2016-071.

Marotta, A. M., \& Spalla, M. I. (2007). Permian-Triassic high thermal regime in the Alps: result of late Variscan collapse or continental rifting? Validation by numerical modelling. Tectonics, 26, 1-27.

Miller, C., Thöni, M., Goessler, W., \& Tessadri, R. (2011). Origin and age of the Eisenkappel gabbro to granite suite (Carinthia, SE Austrian Alps). Lithos, 125, 434-448.

Miller, C. F., McDowell, S. M., \& Mapes, R. M. (2003). Hot and cold granites? Implications of zircon saturation temperatures and preservation of inheritance. Geology, 31, 529-532.

Monjoie, P., Bussy, F., Lapierre, H., \& Pfeifer, H. R. (2005). Modeling of in situ crystallization processes in the Permian mafic layered intrusion of Mont Collon (Dent Blanche nappe, western Alps). Lithos, 83, 317-346.

Monjoie, P., Bussy, F., Schaltegger, U., Mulch, A., Lapierre, H., \& Pfeifer, H. R. (2007). Contrasting magma types and timing of intrusion in the Permian layered mafic complex of Mont Collon (Western Alps, Valais, Switzerland): evindece from $\mathrm{U} / \mathrm{Pb}$ zircon and ${ }^{40} \mathrm{Ar} /{ }^{39} \mathrm{Ar}$ amphibole dating. Swiss Journal of Geosciences, $100,125-135$.

Müntener, O., \& Hermann, J. (2001). The role of lower crust and continental upper mantle during formation of non-volcanic passive margins: evidence from the Alps. Geological Society London Special Publications, 187, 267-288.

Nicot, E. (1977). Les roches méso- et catazonales de la Valpelline (nappe de la Dent Blanche, Alpes Italiennes). PhD dissertation, Université de Paris, Paris, 211.
Oberli, F., Meier, M., Berger, A., Rosenberg, C., \& Gierè, R. (2004). $\mathrm{U}-\mathrm{Th}-\mathrm{Pb}$ and ${ }^{230} \mathrm{Th} /{ }^{238} \mathrm{U}$ disequilibrium isotope systematics: precise accessory mineral chronology and melt evolution tracing in the Alpine Bergell intrusion. Geochimica et Cosmochimica Acta, 68, 2543-2560.

Paquette, J. L., Chopin, C., \& Peucat, J. J. (1989). U-Pb zircon, Rb-Sr and Sm-Nd geochronology of high-to very-high pressure metaacidic rocks from the Western Alps. Contributions to Mineralogy and Petrology, 101, 280-289.

Pearce, N. J. G., Perkins, W. T., Westgate, J. A., Gorton, M. P., Jackson, S. E., Neal, C. R., et al. (1997). A compilation of new and published major and trace element data for NIST SRM 610 and NIST SRM 612 glass reference materials. The Journal of Geostandards and Geoanalysis, 21, 115-144.

Pennacchioni, G., \& Guermani, A. (1993). The mylonites of the Austroalpine Dent Blanche nappe along the northwestern side of the Valpelline Valley (Italian Western Alps). Memorie di Scienze Geologiche, 45, 37-55.

Peressini, G., Quick, J. E., Sinigoi, S., Hofmann, A. W., \& Fanning, M. (2007). Duration of a large mafic intrusion and heat transfer in the lower crust: a SHRIMP U-Pb zircon study in the IvreaVerbano Zone (Western Alps, Italy). Journal of Petrology, 48, $1185-1218$.

Petrík, I., Broska, I., Lipka, J., \& Siman, P. (1995). Granitoid allanite(Ce): substitution relations redox conditions and REE distributions (on an example of I-type granitoids, western Carpathians, Slovakia). Geologica Carpathica, 46, 79-94.

Pouchou, J. L., \& Pichoir, F. (1985). "PAP" phi-rho-Z procedure for improved quantitative microanalysis. In J. T. Armstrong (Ed.), Microbeam Analysis (pp. 104-106). San Francisco: San Francisco Press.

Quick, J. E., Sinigoi, S., Peressini, G., Demarchi, G., Wooden, J. L., \& Sbis, A. (2009). Magmatic plumbing of a large Permian caldera exposed to a depth of $25 \mathrm{~km}$. Geology, 37, 603-606.

Rivalenti, G., Garuti, G., \& Rossi, A. (1975). The origin of the IvreaVerbano basic formation (western Italian Alps) -whole rock geochemistry. Bollettino della Società Geologica Italiana, 94, 1149-1186.

Rivalenti, G., Rossi, A., Siena, F., \& Sinigoi, S. (1984). The layered series of the Ivrea-Verbano igneous complex, Western Alps, Italy. Tschermaks mineralogische und petrographische Mitteilungen, 33, 77-99.

Roda, M., \& Zucali, M. (2008). Meso and microstructural evolution of the Mont Morion metaintrusives complex (Dent Blanche nappe, Austroalpine domain, Valpelline, Western Italian Alps). Italian Journal of Geosciences, 127, 105-123.

Roda, M., \& Zucali, M. (2011). Tectono-metamorphic map of the Mont Morion Permian metaintrusives (Mont Morion-Mont Collon-Matterhorn Complex, Dent Blanche Unit), Valpelline-Western Italian Alps. Journal of Maps, 7, 519-535.

Rubatto, D., Schaltegger, U., Lombardo, B., Colombo, F., \& Compagnoni, R. (2001). Complex Paleozoic magmatic and metamorphic evolution in the Argentera massif (Western Alps), resolved with $\mathrm{U}-\mathrm{Pb}$ dating. Schweizerische mineralogische un petrographische Mitteilungen, 81, 213-228.

Rubatto, D., Hermann, J., Berger, A., \& Engi, M. (2009). Protracted fluid-induced melting during Barrovian metamorphism in the Central Alps. Contributions to Mineralogy and Petrology, 158, 703-722.

Schmid, S. M., Fügenschuh, B., Kissling, E., \& Schuster, R. (2004). Tectonic map and overall architecture of the Alpine orogen. Eclogae Geologicae Helvetiae, 97, 93-117.

Schaltegger, U., \& Brack, P. (2007). Crustal-scale magmatic system during intracontinental strike-slip tectonics: $\mathrm{U}, \mathrm{Pb}$ and $\mathrm{Hf}$ isotopic constraints from Permian magmatic rocks of the 
Southern Alps. International Journal of Earth Sciences, 96, $1131-1151$.

Scherrer, N. C., Engi, M., Gnos, E., Jakob, V., \& Liechti, A. (2000). Monazite analysis; from sample preparation to microprobe age dating and REE quantification. Schweizerische Mineralogische und Petrographische Mitteilungen, 80, 93-105.

Schnetger, B. (1994). Partial melting during the evolution of the amphibolite-to granulite facies gneisses of the Ivrea Zone, northern Italy. Chemical Geology, 113, 71-101.

Schuster, R., \& Stüwe, K. (2008). Permian metamorphic event in the Alps. Geology, 36, 603-606.

Sinigoi, S., Quick, J. E., Clemens-Knott, D., Mayer, A., Demarchi, G., Mazzucchelli, M., et al. (1994). Chemical evolution of a large mafic intrusion in the lower crust, Ivrea-Verbano Zone, northern Italy. Journal of Geophysical Research, 99, 21575-21590.

Sláma, J., Košler, J., Condon, D. J., Crowley, J. L., Gerdes, A., Hanchar, J. M., et al. (2008). Plesovice zircon-a new natural reference material for $\mathrm{U}-\mathrm{Pb}$ and $\mathrm{Hf}$ isotopic microanalysis. Chemical Geology, 249, 1-35.

Smye, A. J., Roberts, N. M. W., Condon, D. J., Horstwood, M. S. A., \& Parrish, R. R. (2014). Characterising the U-Th-Pb systematics of allanite by ID and LA-ICPMS: implications for geochronology. Geochimica et Cosmochimica Acta, 135, 1-28.

Stacey, J. S., \& Kramers, J. D. (1975). Approximation of terrestrial lead evolution by a two-stage model. Earth and Planetary Science Letters, 26, 207-221.

Sun, S. S., \& McDonough, W. F. (1989). Chemical and isotopic systematics of oceanic basalts: implications for mantle composition and processes. In A. D. Saunders \& M. J. Norry (Eds.), Magmatism in ocean basins (42nd ed., pp. 313-345). London: Geological Society of London Special Publications.

Tera, F., \& Wasserburg, G. (1972). U-Th-Pb systematics in three Apollo 14 basalts and the problem of initial $\mathrm{Pb}$ in lunar rocks. Earth and Planetary Science Letters, 14, 281-304.

Thompson, A. B. (1976). Mineral reactions in pelitic rocks: II. Calculation of some $\mathrm{P}-\mathrm{T}-\mathrm{X}(\mathrm{Fe}-\mathrm{Mg})$ phase relations. American Journal of Science, 276, 425-454.
Thompson, A. B., \& Connolly, J. A. D. (1995). Melting of the continental crust: some thermal and petrological constraints on anatexis in continental collision zones and other tectonic settings. Journal of Geophysical Research, 100, 565-579.

Ulianov, A., Müntener, O., Schaltegger, U., \& Bussy, F. (2012). The data treatment dependent variability of U-Pb zircon ages obtained using mono-collector, sector field, laser ablation ICPMS. Journal of Analytical Atomic Spectrometry, 27, 663-676.

Vavra, G., Schmid, R., \& Gebauer, D. (1999). Internal morphology, habit and $\mathrm{U}-\mathrm{Th}-\mathrm{Pb}$ microanalysis of amphibolite-to-granulite facies zircons: geochronology of the Ivrea Zone (Southern Alps). Contributions to Mineralogy and Petrology, 134, 380-404.

Vielzeuf, D., \& Holloway, R. (1988). Experimental determination of the fluid-absent melting relations in the pelitic system: consequences for crustal differentiation. Contributions to Mineralogy and Petrology, 98, 257-276.

von Blanckenburg, F. (1992). Combined high-precision chronometry and geochemical tracing using accessory minerals: Applied to the Central-Alpine Bergell intrusion (central Europe). Chemical Geology, 100, 19-40.

Williams, I. S. (1998). U-Th-Pb geochronology by ion microprobe. In M. A. McKibben, W. C. Shanks III, \& W. I. Ridely (Eds.), Application of microanalytical techniques to understanding mineralizing processes (pp. 1-35). Review in Economic Geology: Society of economic geologists.

Zanetti, A., Mazzucchelli, M., Sinigoi, S., Giovanardi, T., Peressini, G., \& Fanning, M. (2013). SHRIMP U-Pb zircon Triassic intrusion age of the Finero Mafic Complex (Ivrea-Verbano Zone, Western Alps) and its geodynamics implications. Journal of Petrology, 54, 2235-2265.

Zucali, M., Manzotti, P., Diella, V., Pesenti, C., Risplendente, A., Darling, J., et al. (2011). Permian tectonometamorphic evolution of the Dent-Blanche Unit (Austroalpine domain, Western Italian Alps). Rendiconti online Società Geologica Italiana, 15, 133-136. 